Makale Geliş | Received: 09.07.2019.

Mavi Atlas, 7(2)2019: 54-87

Makale Kabul | Accepted: 01.08.2019

DOI: $10.18795 /$ gumusmaviatlas. 586232

Araştırma Makalesi | Research Article

Gülsüm ÇALIŞIR

Doç. Dr. | Assoc. Prof. Dr. Gümüşhane Üniversitesi İletişim Fakültesi Halkla İlişkiler ve Tanıtım Bölümü, Gümüşhane-TÜRKIYYE Gumushane University, Faculty of Communication, Department of Public Relations and Publicity, Gumushane-

TURKEY

ORCID: 0000-0003-3631-6819

gulsumcalisir@yahoo.com

\title{
İhsan TÜRKAL
}

Öğr. Gör. | Lecturer

Gümüşhane Üniversitesi İletişim Fakültesi Halkla İlişkiler ve Tanıtım Bölümü, Gümüşhane-TÜRKIYYE Gumushane University, Faculty of Communication, Department of Public Relations and Publicity, Gumushane-

TURKEY

ORCID: 000-0002-6302-5622 ihstr@yahoo.com

Burak TÜRTEN

Dr. Öğr. Üyesi | Dr. Teaching Member Gümüşhane Üniversitesi İletişim Fakültesi Radyo Televizyon Sinema Bölümü, Gümüşhane, TÜRKIYYE Gumushane University, Faculty of Communication, Department of Radio Television Cinema, Gumushane-

TURKEY

ORCID: 0000-0002-1962-7781 burakturten@gmail.com

Elif KÜTÜKOĞLU

Dr. Arş. Gör. | Dr. Research Assistant Gümüşhane Üniversitesi İletişim Fakültesi Gazetecilik Bölümü, Gümüşhane, TÜRKIYY Gumushane University, Faculty of Communication, Department of Journalism, Gumushane-TURKEY

ORCID: 0000-0001-6203-5303 elifkutukoglu@gmail.com

Caner ÖZARSLAN

Doktora Öğrencisi | PhD Student Atatürk Üniversitesi, Sosyal Bilimler Enstitüsü, İlişkiler ve Tanıtım Bölümü, Erzurum, TÜRKİYE Ataturk University, Faculty of Communication, Department of Public Relations and Publicity, Erzurum, TURKEY ORCID: 0000-0003-4345-470X ozarslancaner@gmail.com 


\title{
Gülsüm ÇALIŞIR, İhsan TÜRKAL, Burak TÜRTEN, Elif KÜTÜKOĞLU, Caner ÖZARSLAN, "Çay İçme Külttürünün Kișilerarası İletişime Katkısı" Mavi Atlas, 7(2)/2019: 54-87
}

\section{Çay İçme Kültürünün Kişilerarası İletişime Katkısı ${ }^{1}$}

$\ddot{\mathbf{O} z}$

Çay, dünyada olduğu kadar ülkemizde de en çok tüketilen içeceklerden birisi haline gelmiştir. Çayın vazgeçilmez olması, onun aynı zamanda sohbetlerin de ortağı olmasına bağlıdır. İki kişi bir araya geldiğinde bir çay söyleyip, iki lafın belini kırma derdine girer. Kültürümüzde yaygın olan çay içme geleneği, özellikle çay ocaklarının, kahvehanelerin ve kafeteryaların artmasıyla birlikte kişilerin birbirleriyle kurdukları iletişimin de en değerli tanığı haline dönüşmüştür.

Çay, iletişim ve kişilerarası iletişime katkı sağlaması bakımından kültürümüzün önemli içeceklerinden birisidir. Söz konusu bu içeceğin misafirlerimize ikram aşamasında ilk tercih edilen içecek olması önemlidir. Yine çayın en çok tüketildiği mekânlardan olan çay ocakları, kahvehaneler ve kafeteryalarda sohbetin başrol oyuncusu olması ve kişilerarası iletişimdeki rolü tartışma götürmez bir gerçektir.

Bu düşüncelerden hareketle çalışmada en fazla tüketildiği mekânlar başta olmak üzere, içildiği her ortamda sohbetlerin başkahramanı olan çayın, kişilerarası iletişime ne denli katkı sağladığı araştırılmıştır. Bu nedenle katılımcılara anket uygulaması yapılmış ve çay içme kültürünün kişilerarası iletişime katkısı incelenmiştir. Çalışmanın örneklemini Gümüşhane ve Erzurum illeri oluşturmuştur. Böylelikle bu çalışmada adı geçen illerde gerçekleştirilen anket sonucunda kültürümüzün bir uzantısı olan çayın, iletişim ve kişilerarası iletişimde oynadığı role ait bilgiler elde edilmiştir.

Anahtar Kelimeler: Çay, Çay İçme, Çay Ocağı, Kahvehane, Kafeterya, Sohbet, İletişim, Kişilerarası İletişim, Sözlü Kültür.

\section{Contribution of Tea Drinking Culture to Interpersonal Communication}

\begin{abstract}
Tea has been one of the most consumed beverages in our country as well as in the world. The indispensability of tea depends on being part of talks as well. When two people come together, they are occupied with ordering tea and shooting the breeze. Custom of drinking tea which is common in our culture has become the most valuable witness for the communication of the people each other as a result of the increase of cafes and cafeterias, especially teahouses.

Tea is one of the significant beverages of our culture in the sense that it makes a contribution to communication and interpersonal communication. It is important that it is the first preferred beverage when we welcome our guests. It is an unquestionably fact that teahouses, cafes and cafeterias in which tea is consumed the most play a significant role in interpersonal communication and chats.

From this point of view, it is researched that the extent of contribution of tea which is leading actor in all consumed places particularly in the places drunk the most to interpersonal communication. Therefore, it was conducted a survey with the participants the contribution of tea drinking culture to interpersonal communication is exemined. The sample of the study is composed of the provinces Gumushane and Erzurum. On this purpose, the datas about the role of the tea which plays in communication and interpersonal communication were collected through the survey carried out in the mentioned provinces.
\end{abstract}

Keywords: Tea, Drinking Tea, Teahouse, Cafe, Cafeteria, Chat, Communication, İnterpersonal Communication, Verbal Culture.

\footnotetext{
${ }^{1} \mathrm{Bu}$ çalışma Gümüşhane Üniversitesi Bilimsel Araştırma Proje Birimi için hazırlanan 17.F3410.02.01 proje kodlu çalışmanın sonuç raporundan üretilmiştir.
} 


\section{Gülsüm ÇALIŞIR, İhsan TÜRKAL, Burak TÜRTEN, Elif KÜTÜKOĞLU, Caner ÖZARSLAN, "Çay İçme Külttürünün Kișilerarası İletişime Katkısı" \\ Mavi Atlas, 7(2)/2019: 54-87}

“Çay, henüz her şey bitmedi demektir. Cezmi ERSÖZ

Sonra belki çay içeriz. Şansımız varsa yağmur da yağar. Damlalara huzur yüklemece oynarız. Benim damlam, seninkini alnından öper. Güzel şeyler olur belki, sen gel bence". Lale MÜLDÜR

\section{Giriş}

Literatürde çay ile ilgili daha önceden yapılan çalışmaların varlığı dikkat çekmektedir. Özellikle yüksek lisans ve doktora tezi olarak araştırılan çay ile ilgili çalışmalarda, çoğunlukla çay sektörü (Korkmaz 2012), çay üretimi (Genç 2012), çay yetiştiriciliği (Çimen 2014) ve çayın marka değerine (Ersöz 2017) ilişkin bilgilere ulaşıldığı görülmektedir. Öte yandan çayın folklorik yönünü (Güneş 2012) ortaya koyan çalışmalarda da daha ziyade kültürel yönünün ön plana çıkartıldığı anlaşılmaktadır. Ancak bugüne kadar çay ve iletişim özelinde kişilerarası iletişimi konu alan bir çalışmaya rastlanmamış olması, böylesi bir çalışma yapılması fikrini ortaya çıkartmıştır.

Ağır ağır yudumlanan çay içme ritüeli, bir dostla yapılan sohbet ile taçlandırılır. $\mathrm{Bu}$ yönüyle bakıldığında çay içme kültürü ve çay içilen mekânlar, kişilerarası iletişime zemin hazırlaması açısından değerlidir. Sıcacık bir çay içerken hem ısınılır hem hararet atılır hem gündeme ilişkin konulardan konuşulur hem de toplumda ne olup bittiği yönünde bilgilenilmiş olunur. Böylelikle çayın çokça tüketildiği mekânlar olan çay ocakları, kahvehaneler ve kafeteryalar; tanışma, buluşma, kaynaşma, iletişime girme ve bu iletişimi sürdürme mekânları olarak görülebilir.

Kişilerarası iletişimin oluşabilmesi için en az iki kişinin bir araya gelmesi ve karşılıklı olarak belli bir konuda sohbet etmesi durumu söz konudur. Bu bağlamda çay ocakları, kahvehaneler ve kafeteryalar, kişilerin buluşma noktaları olmanın yanı sıra kişiler arasında iletişim ortamının yaratılmasına da katkı sağlarlar. Bu düşünceden hareketle bu çalışmada çay ocaklarında, kahvehanelerde ve kafeteryalarda gerçekleştirilen sohbetlerin kişilerarası iletişime ne şekilde katkı sağladığını araştırmak amaçlanmıştır. $\mathrm{Bu}$ amaca ulaşabilmek için söz konu mekânlarda zaman geçiren kişilerle yüz yüze görüşmeler eşliğinde anket yapılarak, çayın kişilerarası iletişime katkılarının neler olabileceği yönünde sorular sorulmuş ve cevaplar alınmıştır. Bu bağlamda bu çalışmada nicel araştırma yöntemi içinde değerlendirilen yüz yüze görüşme yöntemi kullanılarak 800 kişi ile gerçekleştirilen anket uygulanmıştır. Anket 20 maddeden oluşan beşli likert ölçeği ile geliştirilmiştir. Çalışmanın evrenini Gümüşhane ili merkezde ve Erzurum ili merkez ilçelerde yaşayan 18 yaş üstü bireyler oluşturmaktadır. Örneklemi ise 


\section{Gülsüm ÇALIŞIR, İhsan TÜRKAL, Burak TÜRTEN, Elif KÜTÜKOĞLU, Caner ÖZARSLAN, "Çay İçme Külttürünün Kișilerarası İletişime Katkısı" \\ Mavi Atlas, 7(2)/2019: 54-87}

Erzurum ili için \% 5 anlamlılık düzeyinde (\% 95 hata payı ile) 384 kişi olarak belirlenmiş, Gümüşhane ili için ise yine \% 5 anlamlılık düzeyinde 380 kişi olarak tespit edilmiştir. Bu kapsamda çay ocakları, kahvehaneler ve kafeteryalar vb. mekânlarda basit tesadüfi örnekleme yöntemi izlenmiştir.

Çay içme kültürünü ve kişilerarası iletişimi bir arada ele alan bir çalışmanın daha önce yapılmamış olmaması, bu çalışmadan elde edilen bilgilerin literatüre yeni katkılar sağlaması ve diğer araştırmacılara fikir vermesi bakımından önemlidir.

Çalışmada öncelikle çay ve çay içme kültürü üzerine literatürde yer alan genel bilgiler paylaşılmıştır. Sonrasında da çay içme edimi ile kişilerarası iletişim arasındaki bağlantıyı kolaylaştırabilmek için kişilerarası iletişimin ne anlama geldiği açıklanmıştır. Yöntem bölümünde, çalışmada anket uygulaması hakkında bilgiler aktarılmıştır. Çalışmanın bulgular ve tartışma bölümünde ise anket uygulaması sırasında elde edilen bilgiler paylaşılmış ve bunların yorumlaması yapılmıştır. Sonuç bölümünde ise çalışmanın genel bir değerlendirmesi yapılarak, bundan sonra yapılacak çalışmalar için kısaca öneriler sunulmuştur.

\section{Literatür Özeti}

\section{1. Çay ve Çay İçme Kültürü Üzerine}

Çay; birçok efsaneye konu olmuş, pek çok diyarda içilmesinden keyif alınan bir sıvı hâline dönüşmüş, farklı kültürlerde farklı şekillerde içselleştirilerek, uğradığı her yerde bir iz bırakarak günümüze kadar gelmiş ve kendine has bir kültürü oluşturmuş içecektir. Günün her saatinde içimi olan çay ile onu içenler arasında sohbet imkânı oluşurken, aynı zamanda kişilerarası iletişimin gelişimine de katkı sağlanmaktadır.

Çay ve çaya ait kültür, Çin'de ortaya çıkmış ve oradan tüm dünyaya yayılmıştır. Çay kelimesinin doğuşu da aynı şekilde olmuş, öncelikle Çinçede yer almış ve sonrasında diğer dillerde kullanılmıştır. Efsaneye göre ilk kullanımının MÖ 3000 yılına kadar dayandığı belirtilen çayın ne anlama geldiği Batılı kaynaklarda şu şekilde anlatılmıştır: "Çaygiller familyasından küçük bir ağaç ve bu bitkinin dal uçlarındaki yapraklarından hazırlanarak, sıcak ya da soğuk tüketilen içecek" (Ana Biritannica 1986-87'den aktaran: Kuzucu 2012: 3).

Reimertz (2003: 7), Çayın Kültür Tarihi adlı kitabında çayın kökenine ilişkin bilgiler verirken, "İlk çay içildiğinde ufukta ne Musa ne de öteki peygamberler vardı" ifadesini kullanmaktadır. Bu ifadeden yola çıkarak çayın tarihinin MÖ 3000 yılına kadar gittiğini öngörmek mümkündür. Zira çay ile ilgili anlatılan ya da verilen bilgilerden en 


\section{Gülsüm ÇALIŞIR, İhsan TÜRKAL, Burak TÜRTEN, Elif KÜTÜKOĞLU, Caner ÖZARSLAN, "Çay İçme Külttürünün Kișilerarası İletişime Katkısı" \\ Mavi Atlas, 7(2)/2019: 54-87}

eskisi MÖ 2737 yılına dayanmaktadır. Çin'de meydana gelen efsaneye göre adı geçen tarihte İmparator Shen Nung, sarayın bahçesinde sıcak su içerken, rüzgârın da etkisiyle iki yeşil yaprak fincanının içine düşmüştür. Böylece etrafa güzel bir koku yayılmış ve suyun tadı da buruklaşmıştır. Bunun sonucunda imparator, yaprakların yetiştiği bitkinin ne olduğunun bulunması ve her yere ekilmesi talimatını vermiştir. Böylelikle hem çay bitkisi ekimi hem de tüketimi başlamıştır. Çayı ilk bulan kişinin bir imparator olması nedeniyle Çinliler çaya soyluluk atfetmişlerdir (Kuzucu 2012: 6-7).

Çayın kökenine bakıldığında ilk içilen çayın keyif alma duygusunun yanı sıra tıbbi nedenlerle içildiği anlaşılmaktadır. Çünkü çay bin bir derde deva olma özelliğinin yanında zihni uyanık tutma gibi bir duruma da yol açmaktadır. Çay ilk önce Çinliler, sonra da Japonlar tarafından belli ritüeller gözetilerek içilmeye başlanmıştır. Japonlar çayın tarihini belgelendirme konusunda Çin'den daha iyi olmuştur. Böylelikle Japonlar çay içme ritüelini törensel anlamda derinleştirmiş ve çayı törensel yemek kültürlerine uygun biçimde dönüştürerek, kendilerine has bir çay içme töreni haline getirmişlerdir. 17. yüzyılda Avrupa'da keyif maddesi olarak kullanılan çay, 19. yüzyılda Kuzey Denizi civarlarında halk içeceği olarak tüketilmiştir. İngilizler, 17. yüzyılda sömürgesi olan Hindistan aracılığıyla çayla tanışmış ve çayı yaşamlarının vazgeçilmez bir içeceği hâline getirmişlerdir. Rusya'da her ögün çay içilmesi geleneği varken, Fransız entelektüellerinin özel bir çay sevgisi bulunmaktadır. Moğollar ise biraz yağ, bir tutam tuz, biraz un veya darı, hatta açık havada kurutulmuş kuzu etini çaya ekleyerek içerler. Çayın yeryüzüne geliş serüveni, 5000 y1llık bir geçmişe sahiptir (Reimertz 2003).

Dünyada 19. yüzyılın sonu ve 20. yüzyılın başı itibariyle Çin, Japonya, Hindistan, Assam, Rusya, Anadolu, Cava, Seylan, Brezilya ve ABD'de çay yetiştirilmektedir. Çayın dünya ölçeğinde tüketiminin yoğun ilgi görmesiyle birlikte çay yetiştiriciliğinden elde edilen gelirin artmasına ve hatta Avrupa ülkelerinin bu yönde bir sektöre adım atmalarına neden olmuştur. Ancak her bölgenin ikliminin çay yetiştiriciliğine uygun olmaması nedeniyle özellikle Avrupa ülkelerinde çay kültürü, yetiştiricilikten ziyade çoğunlukla tüketimle sınırlı kalmıştır (Kuzucu 2012: 30).

Çayın dünyada geçirdiği serüveni Kacar (2010: 8), şu şekilde özetlemiştir:

-MÖ 2737 Shen Nong döneminde çay keşfedilmiştir,

-MS 479 Moğolistan'da çay ticareti başlamıştır,

-MS 400-600 Çin'de çay, sağlık içkisi olarak kabul edilmiştir,

-MS 593 Budizm ve çay, Çin’den Japonya'ya taşınmıştır, 
Gülsüm ÇALIŞIR, İhsan TÜRKAL, Burak TÜRTEN, Elif KÜTÜKOĞLU, Caner ÖZARSLAN, "Çay İçme Külttürünün Kişilerarası İletișime Katkısı"

Mavi Atlas, 7(2)/2019: 54-87

-MS 780 Çinli bilgin Lu Yu Ch’a “Ching” adlı ilk çay el kitabını yazmıştır,

-MS 805 Japonya' da çay tarımına başlanmıştır,

-MS 1211 Japon budist Abbot Eisai, "Kitcha Yojoki” adında Japonca ilk çay kitabını yazmıştır,

-MS 1559 Venedikliler çayla tanışmıştır,

-MS 1598 İngiliz halkı çay hakkında ilk bilgilere ulaşmıştır,

-MS 1600 çayla ilgili bilgiler Portekiz'e ulaşmıştır,

-MS 1610 Hollandalılar çayı Avrupa'ya getirmiştir,

-MS 1658 çaya ait ilk ilan Londra'da gazetede yayınlanmıştır,

-MS 1684 Java'da çay bitkisinin yetiştirilmesine başlanmıştır,

-MS 1847 çay tarımı SSCB başlamıştır,

-MS 1870 çay tarımı Sri Lanka'da başlamıştır,

MS 1900 Uganda ve Kenya'da çay tarımına başlanmıştır,

-MS 1924 Türkiye'de çayla ilgili kanun çıkarılmış ve Batum'dan tohum getirilmiştir,

-MS 1937 Zihni Derin ile Gürcistan'dan 20 ton tohum satın alınmıştır,

-MS 1939 Gürcistan'dan 30 ton tohum satın alınmıştır,

-MS 1947 Rize'de ilk çay fabrikası işletmeye açılmıştır.

Çaya dair kültür, dünyada böylesi bir tarihsel süreçten geçmiştir. Çayın Türk kültüründeki yerini gösteren arkeolojik kalıntılara bakıldığında ise çayı ilk kullanan Türk kavminin Hunlar olduğu görülmektedir. Coğrafi konumlarının Çin'e yakın olması bakımından onların yeme-içme kültürlerinden etkilendiklerini anlaşılmaktadır. Özellikle MÖ 1. yüzyılın hemen başında ele geçirilen bulgular, bronzdan yapılmış kapların içinde çay kalıntılarının olmasına dayandırılmaktadır. Söz konusu kalıntılar, Türklerin çay içme kültürüne dair en eski bulgular olarak değerlendirilmektedir. Çin'in Tang hanedanının ilk yıllarında (618-907) saray çevresinde tüketimine başlanılan çay, gündelik hayatın bir parçası olmuştur. Bununla birlikte kuzey-güney sınırlarında göçebe olarak yaşayan Moğol, Tatar ve Türk kabileleri arasında sıklıkla tüketilmeye başlanmıştır (Kuzucu 2012: 40). 


\section{Gülsüm ÇALIŞIR, İhsan TÜRKAL, Burak TÜRTEN, Elif KÜTÜKOĞLU, Caner ÖZARSLAN, "Çay İçme Külttürünün Kişilerarası İletişime Katkısı" \\ Mavi Atlas, 7(2)/2019: 54-87}

Çinlilerden öğrendikleri çay kültürünü gittikleri her bölgeye taşıyan Uygurlar, Cengiz Han tarafından egemenliklerinin sonlandırıldığı 1209 yılına kadar çay tüketimine devam etmişlerdir. Zaman zaman başka siyasi oluşumlar içerisinde yer alan Uygur Türklerinin, çay ile ilgili kültürlerini sürdürdükleri yönünde varsayımlar bulunmaktadır (Baykara 2001: 107).

Türklerin Anadolu'ya gelmeden önce de çayı bildikleri, hatta çay ile ilgili oluşturulan kültürün İranlılar ve Ruslardan daha eski olduğu yönünde bilgiler mevcuttur. Ama çayın Türkiye'ye gelerek, Anadolu'da tüketilmeye başlaması 19. yüzyıla rastlamaktadır. Türklerde çayın 12. yüzyılda yaygınlaşmasına ilişkin bir hikâye, Mehmet Fuad Köprülü'nün (2003) Türk Edebiyatında Illk Mutasavvıflar adlı eserinde şu şekilde anlatılmaktadir:

Hoca Ahmet Yesevi bir gün Hitay sınırında Türkistan karyelerinden birine misafir olur. O gün hava çok sıcak olduğu için çok yorulmuştur. Evine misafir olduğu Türkmenin komşusunun zevcesi doğum yapmak üzeredir. Türkmen Hoca Ahmet Yesevi'den dua ister, Ahmet Yesevi de dua eder. Allah'ın izniyle Türkmenin isteği hemen olur. Türkmen bu duruma çok memnun olur. $O$ yörenin önemli bir ikramı olan çay kaynatıp getirir. Hoca Ahmet Yesevi çayı sıcak sıcak içince terler ve yorgunluğu gider. Sonra 'Bu şifalı bir şey imiş, hastalarınıza bundan içirin ki şifa bulsunlar. Allah kıyamete kadar buna revaç versin' diye dua etmiştir. İşte çay bundan sonra bütün Türkler arasında kullanılmaya başlamış ve şifa verici bir içecek olmuştur.

12. yüzyılda Türklerde doğu ile batı arasındaki çay ticareti İpek Yolu üzerinden gerçekleştirilmekteydi. Adı geçen yüzyılda kervanların geçtiği yollara çay tuğlaları denilen tabletler kullanılmıştır. Bunlar, o güzergâhta gerçekleştirilen ticarette çayın değeri hakkında bilgi vermektedir. Mücevher, ipek vb. değerli ticari malları taşıyan kervanların, dinlenmek için verdikleri molalarda çay pişirdikleri ve diğerlerine de ikram ettikleri yönünde bilgiler mevcuttur. Çayı daha önceden bilenlerin yanında ilk kez tadına bakanların da zevkle içtikleri mola yerleri arasında Buhara, Pekin ve Semerkand'da kurulan çayhaneler ilk örnekler olması bakımından önemlidir (Gürsoy 2005: 29-30).

Çayın Anadolu'ya gelişinin 12. ve 13. yüzyılda Haçlı ordularının Anadolu'ya ve Orta Doğu'ya düzenledikleri seferlerle eş zamanlı olduğunu söylemek mümkündür (Oğuz, 1976). 15. yüzyılda çay, Osmanlı'nın çağdaşı olan başka Türk Devletleri arasında başta Moğollar olmak üzere Tatarlar, Kalmuklar ve Buryatlar tarafindan da tüketilen başlıca içecek olarak bilinmektedir. Evliya Çelebi'nin Seyahatname'sinde, Asya'nın orta ve batı bölgelerinde yaşayan Türklerin çay içme alışkanlıklarından söz edilmektedir. Ayrıca Türklerin bu kültürü Tatarlardan öğrenmiş olabilecekleri anlatılmaktadır. Aynı 


\section{Gülsüm ÇALIŞIR, İhsan TÜRKAL, Burak TÜRTEN, Elif KÜTÜKOĞLU, Caner ÖZARSLAN, "Çay İçme Külttürünün Kișilerarası İletişime Katkısı" \\ Mavi Atlas, 7(2)/2019: 54-87}

kültürü Rusların da Tatarlardan edindikleri söylenmektedir. Zira 18. yüzyılda İstanbul'a göç eden Kırım ve Buharalıların da Osmanlıda çay kültürünün yaygınlaşmasına katkı sağladığ1 ve hatta İstanbul'daki ilk çay ticaretinin söz konusu topluluklarca yapıldığ 1 bilinmektedir (Kuzucu 2012: 46-47).

Osmanlı Kültürü ve Gündelik Yaşam adlı eserinde Faroqhi (1997: 234), Osmanlı Devleti'ne çayın giriş yolunu açıklarken, Çin'den Rusya kanalıyla ya da Güneydoğu Asya ile Hicaz güzergâhının kullanıldığını anlatmaktadır. Böylesi bir bakış açısıyla değerlendirildiğinde Van ve Hakkari'de çayın çok demlenmiş olarak ve koyu renkli tüketilmesi, İran'daki içim tarzı ile paralellik göstermektedir. Osmanlı Devleti'nin doğu bölgelerinde çay tüketiminin yoğunluk kazanması, İran ve Rusya gibi çay tüketiminin çok olduğu iki toplumla sınır komşusu olması şeklinde açıklanmaktadır. Örneğin 19. yüzyılda Erzurum eyaletinin sancağı olan Kars, Rusya ve İran ile ticari ilişkilerini çok geliştirmiştir. Bunun sonucu olarak da günümüzde bile Kars ve Erzurum illerinin çay içme alışkanlığının en yaygın yerler olduğu bilinmektedir. Ayrıca Kuzeydoğu Anadolu'da açık ve limonlu çay içilmesi, çayın kıtlama içimi yapılması ve semaver kullanılması gibi alışkanlıkların Rusya'dan Anadolu'ya geçen bir kültür olduğu söylenmektedir (Kuzucu 2012: 50).

1917 yılında Halkalı Yüksek Ziraat Mektebi Müdür Vekili Ali Rıza Erten ve ekibi, çayın Anadolu topraklarında yetiştirilmesi için çay tarımının geliştiği Batum'a teknik bir gezi düzenlemiştir. Bu gezinin amac1, Rize yöresinin toprak ve iklim özelliklerinin Batum'a benzerlik göstermesinden kaynaklı olarak burada da çay yetiştirilebileceğini araştırmak olmuştur. Bu konuda İktisat Vekâleti'ne "Şimali Şarki Anadolu ve Kafkasya'da Tetkikatı Zirai” adlı bir rapor sunulmuştur. Adı geçen rapor ilerleyen süreçte 1. Dünya Savaşı yaşanması gerekçe gösterilerek, 1924 yılına kadar dikkate alınmamıştır. Söz konusu tarihte ise çay, mandalina, portakal yetiştirilmesini teşvik etmek amaciyla 407 sayılı Kanun çıkarılmıştır. Dönemin Ziraat Umum Müdürü Zihni Derin'in çay üretimine ilişkin katkıları olmuş ve ilk ürün 1938 yılında alınmıştır. 1940 yılında çay tarımı ve üretimini desteklemek için "Çay Kanunu” çıkarılmış, 1942 yılında 4223 sayılı Kanun'la çay üretimi, işlenmesi ve pazarlanması devlet tekeline alınmış ve ilk çay fabrikası 1947 yılında Rize'de kurulmuştur. 1984 tarih 3092 sayılı Çay Kanunu ile çay üzerindeki devlet tekeli kaldırılmış ve çay üretimi, işlenmesi ve pazarlanmasının özel sektöre de açılmasıyla çay sektöründe köklü değişiklikler yaşanmıştır (Kalça-Toksoy 2006, Taşkın 2007 ve Duman 2008'ten aktaran: Güneş 2012: 236). 


\section{Gülsüm ÇALIŞIR, İhsan TÜRKAL, Burak TÜRTEN, Elif KÜTÜKOĞLU, Caner ÖZARSLAN, "Çay İçme Külttürünün Kişilerarası İletişime Katkısı" \\ Mavi Atlas, 7(2)/2019: 54-87}

Türklerin tarihinde çay ve çaya dair kültür, dünyanın çeşitli ülkelerine göre daha geç oluşmuştur. Ancak söz konusu kültürün izleri kalıcı olmuştur. Çünkü Türklerin yaşamına geç girmesine karşın çay, bugün oluşturduğu kültürü ile birlikte sosyal yaşamda yeri doldurulamayacak bir değer hâline gelmiştir. Böylece birçok kültür tarafından el üstünde tutulan bu içecek, Türk kültürüne hızlı uyum sağlamıştır. Bu kaynaşmanın sonucunda çayın üretilmesinden tüketilmesine kadar olan süreçte Türkler tarafından birçok düşünsel yenilik sunulmuştur. Gün boyu çay içme geleneğinin yaygınlaşmasıyla birlikte, Türklerin çay içme kültürünün oluşmasına da ciddi katkıları olduğu ileri sürülmektedir. Buna göre çay demleme usulü, çay içilen bardakların inceliği vb. konularında adı geçen kültüre, Türkler tarafından zenginlik kazandırılmıştır (http://www.kerimusta.com, 2018).

Halk kültürü ve etnografyasında çay önemli bir yer tutmaktadır. Çay, bugün sosyal hayatımızda yerini dolduramayacak derecede sağlamlaştırmış onun etrafında oluşan kültürüyle birlikte yaşamaktadır. Sabah kahvaltısından gecenin geç saatlerine kadar hayatımızın içinde bulunan çay, değişik kültürel değerlerin ortaya çıkmasına sebep olmuştur. Yetiştirilmesinden hazırlanıp tüketilmesine varana kadar olan çay kültürü, bir çay etnografyasını da ortaya çıkarmıştır. Çay kesilmesine yarayan makaslar, sepetler, kutular, demlikler, semaverler, çay kazanları, bardaklar, fincanlar, kaşıklar, tepsiler vb. hepsi çay kültürünün etrafında oluşan etnografik maddelerdir (Güneş 2012: 235).

Türkler, dünden bugüne gün boyunca içilen çaya kendi yaşam şartlarının uzantısı olarak yeni kültürel değerler kazandırmıştır. Bunlardan en çok dikkat çekeni demli çay, çayı ince belli bardakta içme ve kıtlama çay içme geleneğidir. $\mathrm{Bu}$ unsurlar Türkler tarafından çay kültürüne eklemlenen öğeler olmuştur. Bunun yanı sıra çay ve çay içme kültürü denildiğinde ülkemizde Erzurum ve Rize illeri dikkat çekmektedir. Çünkü çay Rize'de yetiştirilir; ama en çok da Erzurum'da içilir, durumu söz konusudur. Tezcan (1987: 280) Erzurum'daki çay içme geleneği ve çay kültürüne dair düşüncelerini şu şekilde anlatmaktadır:

Erzurum kültürünün karakteristik özelliklerinden birisi de çay içme geleneğidir. Çay, bir kültür karmaşığı oluşturmuştur. Çünkü çay içemeye ilişkin gelenekler, davranışlar mevcuttur. Ülkemizde en çok çay içilen ve çayı seven illerimizden birisidir. Karadeniz'de yetiştirilen çay, Doğu Anadolu'da içilir. Erzurum, bunların başında gelmektedir. Erzurum'da çay şekeri de farklıdır. Erzurum fabrikasında yapılan ve çuvallarla satılan kelle şeker, özel bir çekiçle 'taka tuka' denilen özel bir kabın içinde kırılır. Bu şekerin bir parçası çaya batırılıp, dilin altına konur ve çay, yudum yudum içilir. Dil altındaki şeker de bardaktaki çay bitince erir. Çay koymak anlamında 'çay dökmek' veya 'çay tazelemek' 


\section{Gülsüm ÇALIŞIR, İhsan TÜRKAL, Burak TÜRTEN, Elif KÜTÜKOĞLU, Caner ÖZARSLAN, "Çay İçme Külttürünün Kişilerarası İletişime Katkısı" \\ Mavi Atlas, 7(2)/2019: 54-87}

deyimleri kullanılır. Çay ikramı kabul etmemek, ayıp sayılır. Çay içmek, bir alışkanlık haline gelir. Bir Erzurumlu 'Bir çay içim de kendime gelim' sözünü sıklıkla kullanır.

Çay içme geleneği ve kültürü, Türklerin gündelik yaşantısında çok yer kaplamaktadır. Hatta öyle ki, folklorik değerlerine bile konu olmuştur. Tezcan'ın (1987: 282) İhsan Coşkun Atılcan'dan aktardığı “Çayname” adlı şiiri, çay kültürüne dair bilgiler vermektedir:

Akar gider Akpınar'ın suları,

Yazıcısı daha birçok pınarı,

Tabakhane, Cennet, çeşme suları,

İçmezler de ile de olsun "taze çay".

Dilde destan kışları ve barları,

Yaylasında kısrakları tayları,

Sularından nefis olur çayları,

Dadaşların tutkusudur burada çay.

Çay üretiminde Türkiye, dünyada büyük bir pazara sahiptir. Çay üretiminde olduğu kadar tüketiminde de Türkiye dikkat çeken bir noktadadır. Bu anlamda Türkiye'de siyah çay içimi Türk yaşam tarzı ve kültürünün ayrılmaz bir parçası olmuştur. Çayın, kahveye oranla daha ucuz ve hazırlık evresinin daha kolay olması, kısa sürede yaygınlaşmasına ve halkın en sevdiği içecek olmasına neden olmuştur (Duman, 2008). Çay aynı zamanda dostluk ve misafirperverliğin de bir göstergesi olarak kullanılmaktadır. Washington Times gazetesi yazarlarından Gerald Robins, çayın Türk hayatındaki önemine dair şunları dile getirmiştir: "Türkiye'de her iş kültürel alışkanlıkların çevresinde sonuçlandırılır. Ankara'da bürokrasi ile tanışanlar bunu çok iyi bilirler. Örneğin başkent Ankara'da Türk tipi bardaklarda sunulan çay ikramından önce hiçbir şey başlamaz. Çayın yanında sigara sunulması, ardında dostça ve filozofça uzun uzun laf edilmesi, yerleşik iş kültürünün uzantısı olmuştur.” (Aktaran: Güneş 2012: 238).

Türkiye'de çay kültürünün yaygınlığı, hemen her ortamda çay ikram edilmesi ile anlaşılmaktadır. Hatta öyle ki sadece çay hazırlamak ve ikram etmek için çay ocakları, çayhaneler ve bu işi meslek edinmiş çaycılar bulunmaktadır. Günümüzde adı kahvehane olan yerlerde bile artık çoğunlukla çay tüketilmektedir. Tüketim geleneğinin kahveden çaya evrilmesinin birkaç nedeni vardır. Bunlar arasında 2. Dünya Savaşı sonrasında 


\section{Gülsüm ÇALIŞIR, İhsan TÜRKAL, Burak TÜRTEN, Elif KÜTÜKOĞLU, Caner ÖZARSLAN, "Çay İçme Külttürünün Kişilerarası İletişime Katkısı" \\ Mavi Atlas, 7(2)/2019: 54-87}

kahvenin ithalatında yaşanan sıkıntılar, ülkemizde özellikle de Doğu Karadeniz'de çay üretiminin yaygın olması ve sıvı ihtiyacının çoğunun çayla karşılanması gibi özellikler bulunmaktadır (Gürsoy 2005: 14).

Akdeniz kültürünün bir uzantısını yaşayan Türk insan1, sıcakkanlı olması nedeniyle sohbet etmeyi de çok sevmektedir. Türkiye'de insanların bir araya gelerek sohbet ettiği, zaman geçirdiği, dinlendiği, eğlendiği, günün sıkıntısını atmaya çalıştığı mekânların başında çay ocakları gelmektedir. Hal hatır sorma ile başlayan, sonrasında dünya ve Türkiye gündemine ilişkin pek çok politik konuyu da içeren sohbetlere eşlik eden çay içme geleneğinden söz etmek mümkündür. Çay ayrıca Türk ev kültürünün de bir uzantısıdır. Çünkü sabah kahvaltısı ile başlayan çay içme kültürü, günün ilerleyen saatlerinde de devam etmektedir. Türkler, çayı sırf içmek için içmezler ve ona bir anlam yüklerler. Çay, Türkler için koyu sohbetlerin ortağı konumundadır. Bu yönüyle bakıldığında çay, iletişim ortamının doğmasına ve gelişmesine katkı sağlayan araçlardan biri haline gelmiştir.

Çay ve ona ait kültürün kişilerarası iletişime katkılarına ilişkin olarak anlatılan güzel bir hikâyesi vardır. Çeşitli ortamlarda anlatılan bu hikâyede özneler, aile bireyleridir. Hikâye şu şekildedir:

Üst demlik; gelindir, alt demlik kaynadıkça onun harareti artar; ama aynı zamanda olgunlaşır ve çay demlenir. Bardak; gelinin kocasıdır. Her iki çaydanlıktan da yeterince nasibini alır. Biraz kaynana doldurur, biraz da gelin. Bu nedenle denge unsuru çok önemlidir. Açık ya da demli çayın hoşa gitmemesi bundandır. Çayın şekeri; ise çocuklardır. Çaya tat verir; fakat çok şeker çayın lezzetini bozar. Şekersiz çaya alışanlar için ise bir tanesi bile fazla gelebilir. Çay kaşığı; görümcedir. Arada bir gelir karıştırır ve gider. Kayınpedere gelince; o da çay tabağıdır. Çayın demine suyuna hiç karışmaz, bir köşede sessiz sedasız bir şekilde oturur. Sadece dökülenleri toplar ve çevreye zarar vermesini engeller. Ancak ara sıra boşaltmak gerekir; yoksa taşıp her şeyi berbat edebilir. Çay süzgeci; ailenin sahip olduğu değerlerdir. Aileyi dış müdahalelerden korur. Delikleri büyük olursa çayın tadı kaçabilir. Suyu ısıtan ateş ise hoşgörüdür, o olmadan hoşgörü de olmaz. Kısacası bir bardak çay, ailedir ve ağız tadıyla içilen bir bardak çayın üstüne yoktur... (http://medyamutfagi.blogcu.com, 2018)

Bu yönüyle de bakıldığında çay, birileriyle birlikte içilmesinden ve sohbetlerin baş taşı olmasından kaynaklı olarak, kişilerarası iletişime de katkı sağlayan bir araç olarak düşünülebilmektedir. İnsanlar arasındaki samimi ortamın yaratılması, bu samimiyetin sürdürülebilmesi yeri geldiğinde bir bardak çayla mümkün olabilmektedir. Böylelikle çay ile kişilerarası iletişim arasında bir bağlantıdan söz etmek mümkün olmaktadır. Bu 


\section{Gülsüm ÇALIŞIR, İhsan TÜRKAL, Burak TÜRTEN, Elif KÜTÜKOĞLU, Caner ÖZARSLAN, "Çay İçme Külttürünün Kișilerarası İletişime Katkısı" \\ Mavi Atlas, 7(2)/2019: 54-87}

bağlamda konunun kişilerarası iletişim boyutunun da ele alınması, iki kavram arasındaki bağlantıyı gösterebilmek adına gerekli görülmüş ve ilgili kavram aşağıda açıklanmıştır.

\subsection{Kişilerarası İletişim}

Kişilerarası iletişim, insanoğlunun yaşamı boyunca vazgeçemeyeceği bir olgudur. İnsan, doğası gereği sosyal bir varlıktır. $\mathrm{Bu}$ özelliği nedeniyle birçok ihtiyacı bulunmaktadır. Söz konusu ihtiyaçlar arasında açlık, susuzluk, cinsellik gibi temel ihtiyaçlar başı çekmektedir. Ancak insanın sevmek, sevilmek, paylaşmak, başka bireylerle ilişki kurmak gibi sosyal ihtiyaçları da vardır. Bunun için diğer insanlarla kurulan ilişki ve iletişimin niteliği, kişinin yaşamı üzerinde önemli etkilere sahiptir. İnsan, yaşamı boyunca pek çok sorunla karşı karşıyadır ve bunların çoğunun da diğer insanlarla kurulan iletişimle bağlantılı olduğunu ifade etmek mümkündür. $\mathrm{Bu}$ durumun kişinin lehine sonuçlandırılmasında, insanın çevresindekilerle sağlıklı bir iletişim gerçekleştirmesi önemli bir rol oynamaktadır. Görüldüğü gibi sağlıklı bir iletişimin kurulması ve sürdürülebilir olmasında kişilerarası ortamda sergilenen tavrın önemi büyüktür. Bu nedenle kişilerarası iletişim önemlidir.

Kişilerarası iletişim, kaynağını ve hedefini insanların oluşturduğu ve en az iki kişi arasında bilgi ve sembol üreterek, bunları aktarmak ve yorumlamak için yüz yüze gerçekleşen iletişime denilmektedir (Dökmen 2001: 23; Hartley 2010: 41). Bir iletişimin kişilerarası iletişimin sayılabilmesi için; kişilerarası iletişime katılanlar belli bir yakınlık içinde yüz yüze olmalıdır; katılımcılar arasında tek yönlü değil karşılıklı bir mesaj alışverişi olmalıdır, söz konusu mesajlar sözlü ve sözsüz nitelikte olmalıdır (Tubbs ve Moss, 1991'den aktaran: Dökmen 2001: 24).

Kişilerarası iletişim, iki ya da daha fazla kişi arasında gerçekleşen, kimsenin aracılık etmediği, kişilerarası ilişkilerin bir sonucu olarak karşılıklı ilgi, samimiyet ve açıklığın vurguladığı bir iletişim şeklidir. Bu yönüyle kişilerarası iletişim, insanlar arasında gerçekleşen ve insana dair bir iletişim olarak ifade edilmektedir (Ruffner ve Burgoon 1981: 9). Usluata'nın (1994: 51), Katz (1964)'tan yaptığı aktarıma göre kişilerarası iletişim, "etkileşim" demektir. Buna göre iki ya da daha çok kişinin birbirlerinin sözlü ya da sözsüz etkinliklerini göz önünde bulundurduklarında, ilişkinin biçimlenmesi ve gelişmesi sonucunda ortaya çıkan ilişsinin türüne kişilerarası iletişim denilmektedir.

Gürüz ve Temel Eğinli (2012: 54), kișilerarası iletişimi iki kişi arasında gerçekleşen etkileşim sonucunda anlam yaratılması ve anlamın paylaşılması süreci olarak tanımlayarak, adı geçen süreçle ilgili olarak şu şekilde bir açıklamaya gitmişlerdir: 


\title{
Gülsüm ÇALIŞIR, İhsan TÜRKAL, Burak TÜRTEN, Elif KÜTÜKOĞLU, Caner ÖZARSLAN, "Çay İçme Külttürünün Kişilerarası İletişime Katkısı" \\ Mavi Atlas, 7(2)/2019: 54-87
}

\begin{abstract}
Bu tanımın içerisinde süreç, mesaj etkileşimi, anlam paylaşılması olmak üzere üç bileșen bulunmaktadır. Kișilerarası iletișim bir süreçtir; yani sürekliliği olan, sonu bulunmayan, coşkulu bir aktivite olup sürekli değişmektedir. İki kişi arasında geri çevrilemez bir süreçtir. Diğer bir nokta mesajların değişimi, iki kişi arasında karşı1ıklı olarak sözlü ve sözsüz mesajların gönderilmesi ve alınması söz konusudur. Hem sözlü hem de sözsüz mesajlar, bir daire olarak etkileşimde bulunmakta, iletişimde bulunanları etkilemektedir. Ancak mesajların kişilerarasında aktarılması yeterli değildir, mesajların anlam yaratması gerekmektedir. İlişkisel süreç içinde iki kişi arasında anlam yaratılması ve anlam paylaşılması söz konusu olmaktadır. Bununla birlikte, kişilerarasında iyi ya da kötü ilişkisel deneyimlerin var olması, mesajların anlamlandırılmasını etkilemektedir.
\end{abstract}

Kişilerarası iletişim en az iki kişi arasında mesajların formüle edilerek alıcı ve kaynak arasında algılama ve anlamlandırma yoluyla gerçekleşmektedir. Kişilerarası iletişimde kişinin kim olduğu, ne bildiği, neye inandığı, ne söylediği, ne istediği, nasıl söylediği, neler duyduğu, mesajları nasıl aldığı ve cevapladığı önemlidir. Çünkü verilen tepkiler bu ölçülere göre değişmektedir. Bu durum kişilerarası iletişim sürecinin nasıl işlediği ve öğelerinin neler olduğu konusunda bize bilgiler vermektedir (Devito 1995: 1019). Ayrıca bir iletişimin kişilerarası iletişim sayılabilmesi için; iletişimi gerçekleştirenlerin yüz yüze ve bir etkileşimde olmaları; tek yönlü değil, çift yönlü ileti alışverişinde bulunmaları; iletilerini sözlü ya da sözsüz olacak şekilde zaman ve mekân bağlamında iletmeleri gerekmektedir (Özgüven 2001'den aktaran: Siyez 2015: 62).

Gürüz ve Temel Eğinli (2012: 70), kişilerarası iletişim araştırmacıları olan Paul Watzlawick, Janet Helmick Beavin, Don D. Jackson tarafından ifade edilen kişilerarası iletişim sürecinde, sürecin nasıl işlediğine ve temel özelliklerin neler olduğuna dair varsayımları şu şekilde özetlemişlerdir:

- Kişilerarası iletişim, karşılıklı bir etkileşim sürecidir.

- Kişilerarası iletişim, bir süreçtir.

○ Kişilerarası iletişim unsurları, birbirine bağlıdır.

- Kişilerarası iletişim, kaçınılmazdır.

- Kişilerarası iletişim, tersine çevrilemez ve tekrarlanamaz.

- Kişilerarası iletişim, kültür temellidir.

- Kişilerarası iletişim, bir düzenleme sürecidir.

- Kişilerarası ilişkiler, simetrik ve tamamlayıcıdırlar.

- Kişilerarası iletişimlerde içerik ve ilişki boyutları bulunmaktadır. 


\section{Gülsüm ÇALIŞIR, İhsan TÜRKAL, Burak TÜRTEN, Elif KÜTÜKOĞLU, Caner ÖZARSLAN, "Çay İçme Külttürünün Kişilerarası İletişime Katkısı" \\ Mavi Atlas, 7(2)/2019: 54-87}

Görüldüğü gibi sosyal bir varlık olan insanın çevresiyle ilişki kurma isteği, onu kişilerarası iletişimin öznesi konumuna getirmiştir. Çünkü adı geçen iletişim türünde en az iki insanın varlığı söz konusudur. Bir araya gelen iki insanın aralarında gerçekleşen iletişim bu anlamda bir süreçten meydana gelirken, kaçınılmaz bir şekilde ortaya çıkmakta ve içinde var olduğu kültürün uzantılarını taşımaktadır.

\section{Gereç ve Yöntem}

Bu çalışmadaki amaç, çay içme kültürünün kişilerarası iletişime katkısının ne olduğunu araştırmaktır. Bir başka deyişle, araştırmada bireylerin çay içme kültürlerinin onların diğer insanlarla olan iletişimleri üzerinde bir katkısı olup olmadığı karşılaştırmalı olarak saptanmak istenmiştir. Aynı zamanda seçili demografik değişkenler ile çay içme kültürü arasında bir ilişki olup olmadığı ölçülmeye çalışılmıştır. Araştırma kapsamında, gerekli bilgiler yüz yüze görüşme yapılarak anket yöntemi ile toplanmıştır. Bu doğrultuda 20 maddeden oluşan beşli likert ölçeği (1=kesinlikle katılmıyorum, 5=kesinlikle katılıyorum) kullanılmıştır. Araştırmacılar tarafından geliştirilen ölçek formu ilk olarak 100 kişiye uygulanmış, geçerlik ve güvenirlik testlerine tabi tutulmuştur. Güvenlik ve geçerlik testleri sonucunda ölçeğin araştırma için uygun olduğuna karar verilerek, araştırma anketinin uygulanmasına geçilmiştir.

Araştırmanın evrenini Gümüşhane ili merkezde (39.150) ve Erzurum ili merkez ilçelerde (265.200) yaşayan 18 yaş üstü bireyler oluşturmaktadır. Örneklemi ise Erzurum ili için \% 5 anlamlılık düzeyinde (\% 95 hata payı ile) 384 kişi olarak belirlenmiş, Gümüşhane ili için ise yine \% 5 anlamlılık düzeyinde 380 kişi olarak tespit edilmiştir. Bu kapsamda çay ocakları, kahvehaneler ve kafeteryalar vb. mekânlarda basit tesadüfi örnekleme yöntemi izlenmiştir. Bir kısım anketlerin geçersiz olabileceği de göz önünde bulundurularak, söz konusu mekânlarda 800 kişi üzerinde anket uygulanmıştır.

Araştırma kapsamında oluşturulan hipotezler aşağıdaki gibidir:

H1: Katılımcıların cinsiyetlerine göre çay içme kültürleri farklılaşmaktadır.

H2: Katılımcıların medeni durumlarına göre çay içme kültürleri farklılaşmaktadır.

H3: Katılımcıların eğitim durumlarına göre çay içme kültürleri farklılaşmaktadır.

H4: Katılımcıların gelirlerine göre çay içme kültürleri farklılaşmaktadır.

H5: Katılımcıların yaşlarına göre çay içme kültürleri farklılaşmaktadır.

H6:Katılımcıların bulunduğu mekâna göre çay içme kültürleri farklılaşmaktadır.

H7:Katılımcıların çay içme saatlerine göre çay içme kültürleri farklılaşmaktadır. 
Gülsüm ÇALIŞIR, İhsan TÜRKAL, Burak TÜRTEN, Elif KÜTÜKOĞLU, Caner ÖZARSLAN, "Çay İçme Kültürünün Kişilerarası İletişime Katkısı"

Mavi Atlas, 7(2)/2019: 54-87

\section{Bulgular ve Tartışma}

Araştırma kapsamında kullanılan anket ölçeğine katılımcıların verdiği yanıtlara ilişkin betimsel istatistikler Tablo 1'de verildiği şekliyledir. Tabloda ölçeğe ilişkin bazı maddelerin verilmediği görülmektedir. Bunun temel nedeni ise tablo oluşturulurken faktör analizi sonuçlarının göz önünde bulundurulmasıdır.

Tablo 1. Ölçek maddelerine ilişkin betimsel istatistikler

Gümüşhane

Erzurum

\begin{tabular}{|c|c|c|c|c|c|c|c|}
\hline & $\mathbf{N}$ & Min. & Max. & Ort. & S. S. & Ort. & S. S. \\
\hline Çay içmek beni rahatlatır. & 399 & 1 & 5 & 3.95 & 1.169 & 4.08 & 1.137 \\
\hline Çay içmek insanı rahatlatır. & 399 & 1 & 5 & 3.90 & 1.069 & 3.95 & 1.082 \\
\hline Stresli ve gergin olduğumda çay içmek iyi gelir & 399 & 1 & 5 & 3.71 & 1.205 & 3.70 & 1.236 \\
\hline Sorunları çözerken çay içmek, insanı sakinleştirir. & 399 & 1 & 5 & 3.60 & 1.154 & 3.59 & 1.191 \\
\hline Başkaları ile birlikte çay içmek, insanı mutlu eder. & 399 & 1 & 5 & 4.09 & 1.059 & 4.16 & 1.069 \\
\hline Arkadaşlarımla çay içmek keyiflidir. & 399 & 1 & 5 & 4.21 & .937 & 4.30 & .989 \\
\hline Aile bireyleri ile çay içmek keyiflidir. & 399 & 1 & 5 & 4.28 & .922 & 4.33 & 1.019 \\
\hline $\begin{array}{l}\text { Çay içmek, kişiler arasındaki iletişimin devam } \\
\text { etmesine yardımcı olur. }\end{array}$ & 399 & 1 & 5 & & & 3.87 & 1.144 \\
\hline $\begin{array}{l}\text { Çay içmek, kişiler arasındaki samimiyetin } \\
\text { gelişmesine yol açar. }\end{array}$ & 399 & 1 & 5 & & & 3.90 & 1.087 \\
\hline $\begin{array}{l}\text { Çay içmek, sohbetlerin derinlik kazanmasına yol } \\
\text { açar. }\end{array}$ & 399 & 1 & 5 & 3.87 & 1.090 & 3.95 & 1.086 \\
\hline $\begin{array}{l}\text { Çay içmek, kişiler arası iletişim aracı olarak } \\
\text { kullanılabilir. }\end{array}$ & 399 & 1 & 5 & 3.73 & 1.124 & 3.78 & 1.112 \\
\hline Çay içmek, sırların paylaşılmasına yardımcı olur. & 399 & 1 & 5 & 3.31 & 1.268 & 3.20 & 1.298 \\
\hline Çay içmek, dertlerin paylaşılmasına yardımcı olur. & 399 & 1 & 5 & 3.55 & 1.208 & 3.60 & 1.217 \\
\hline Çay içmek, dostluk ilişkilerini güçlendirir. & 399 & 1 & 5 & 3.78 & 1.099 & 3.79 & 1.183 \\
\hline
\end{tabular}


Gülsüm ÇALIŞIR, İhsan TÜRKAL, Burak TÜRTEN, Elif KÜTÜKOĞLU, Caner ÖZARSLAN, "Çay İçme Kültürünün Kişilerarası İletişime Katkısı"

Mavi Atlas, 7(2)/2019: 54-87

\begin{tabular}{|c|c|c|c|c|c|c|c|}
\hline Çay içmek, insan ilişkilerine olumlu katkı sağlar. & 399 & 1 & 5 & 3.85 & 1.027 & 3.86 & 1.147 \\
\hline $\begin{array}{l}\text { Çay içmenin insanları bir araya getirme/toplama } \\
\text { özelliği vardır. }\end{array}$ & 399 & 1 & 5 & 4.13 & .997 & & \\
\hline Çay içmek, başkaları ile olan ilişkileri pekiştirir. & 399 & 1 & 5 & 3.77 & 1.122 & 3.85 & 1.126 \\
\hline
\end{tabular}

Tablo 1 incelendiğinde katılımcıların anket sorularına vermiş oldukları yanıtların ortalamasının oldukça yüksek olduğu görülmektedir. Buradan hareketle katılımcıların anket sorularını anlayarak cevaplandırdıkları sonucunu çıkarmak mümkündür. İstatistiksel bulgulara göre her iki örneklem grubundaki katılımcıların aileleri, arkadaşları ve diğer insanlar ile çay içmeyi çok önemsedikleri (her iki örneklem grubunda ilgili maddelere verilen yanıtların ortalaması 4'ün üzerindedir) görülmüştür. Bu durum, çayın kalabalık gruplarla birlikte içilmesinin tercih edilen bir durum olduğunu göstermesi bakımından önemli bir bulgu olarak değerlendirilebilir. Bu yönüyle değerlendirildiğinde ilgili bulgu, araştırmanın çıkış noktasıyla da bağlantı kurması bakımından değerli bir sonuç olarak yorumlanabilir. Zira çay içme edimi gerçekleştirilirken genellikle yanımızda tanıdıklarımızın olmasını tercih etmek istememiz, iletişim ortamının yaratılması hususunda da önemli gelişme olarak değerlendirilebilir.

Araştırmaya katılan katılımcıların frekans istatistiklerine yönelik bilgiler ise aşağıda gösterilen Tablo 2'de verildiği gibidir.

Tablo 2. Katılımcıların demografik bilgilerine ilişkin frekans istatistikleri

\begin{tabular}{|c|c|c|c|c|}
\hline Değişken & \multicolumn{2}{c}{ Gümüşhane } & \multicolumn{2}{c}{ Erzurum } \\
\hline Yaş & Sayı (N) & Yüzde (\%) & Sayı (N) & $\begin{array}{c}\text { Yüzde } \\
(\%)\end{array}$ \\
\hline $18-25$ arası & 105 & 26.3 & 179 & 35.2 \\
\hline 26-30 arası & 68 & 17.0 & 68 & 13.4 \\
\hline $31-45$ arası & 142 & 35.6 & 112 & 22.0 \\
\hline $46-55$ arası & 40 & 10.0 & 27 & 5.3 \\
\hline 56 ve üstü & 43 & 10.8 & 12 & 2.4 \\
\hline Gelir & & & & \\
\hline
\end{tabular}


Gülsüm ÇALIŞIR, İhsan TÜRKAL, Burak TÜRTEN, Elif KÜTÜKOĞLU, Caner ÖZARSLAN, "Çay İçme Külttürünün Kişilerarası İletişime Katkısı"

Mavi Atlas, 7(2)/2019: 54-87

\begin{tabular}{|c|c|c|c|c|}
\hline $750-1750$ aras1 & 63 & 15.8 & 57 & 11.2 \\
\hline $1755-3500$ aras 1 & 182 & 45.6 & 124 & 24.4 \\
\hline $3550-4500$ aras 1 & 78 & 19.5 & 66 & 13.0 \\
\hline $4550-5500$ aras 1 & 32 & 8.0 & 45 & 8.8 \\
\hline 5550 ve üstü & 44 & 11.0 & 98 & 19.3 \\
\hline \multicolumn{5}{|l|}{ Cinsiyet } \\
\hline Erkek & 183 & 45.6 & 226 & 44.4 \\
\hline Kadın & 216 & 54.1 & 171 & 33.6 \\
\hline \multicolumn{5}{|l|}{ Medeni Durum } \\
\hline Evli & 229 & 57.4 & 156 & 30.6 \\
\hline Bekâr & 170 & 42.6 & 243 & 47.7 \\
\hline \multicolumn{5}{|l|}{ Ĕ̆itim Durumu } \\
\hline İlköğretim & 65 & 16.3 & 32 & 6.3 \\
\hline Lise & 104 & 26.1 & 84 & 16.5 \\
\hline Ön lisans & 77 & 19.3 & 54 & 10.6 \\
\hline Lisans & 110 & 27.6 & 164 & 32.2 \\
\hline Lisans Üstü & 43 & 10.8 & 65 & 12.8 \\
\hline \multicolumn{5}{|c|}{ Çayın en fazla içildiği mekân } \\
\hline Çay ocağ1 & 67 & 16.8 & 56 & 11.0 \\
\hline Kahvehane & 33 & 8.3 & 69 & 13.6 \\
\hline Kafe & 35 & 8.8 & 49 & 9.6 \\
\hline Okul-kantin & 23 & 5.8 & 40 & 7.9 \\
\hline Ev & 146 & 36.6 & 137 & 26.9 \\
\hline
\end{tabular}


Gülsüm ÇALIŞIR, İhsan TÜRKAL, Burak TÜRTEN, Elif KÜTÜKOĞLU, Caner ÖZARSLAN, "Çay İçme Kültürünün Kişilerarası İletişime Katkısı"

Mavi Atlas, 7(2)/2019: 54-87

\begin{tabular}{|c|c|c|c|c|}
\hline İşyeri & 95 & 23.8 & 48 & 9.4 \\
\hline Çayın en fazla içildiği saatler & & & & \\
\hline $05.00-09.00$ & 19 & 4.8 & 26 & 5.1 \\
\hline $09.01-13.00$ & 106 & 26.6 & 85 & 16.7 \\
\hline $13.01-17.00$ & 114 & 28.6 & 102 & 20.0 \\
\hline $17.01-21.00$ & 128 & 32.1 & 134 & 26.3 \\
\hline $21.01-01.00$ & 27 & 6.8 & 45 & 8.8 \\
\hline $01.01-04.59$ & 5 & 1.3 & 7 & 1.4 \\
\hline
\end{tabular}

Tablo 2 incelendiğinde Gümüşhane ilinden araştırmaya katılanların büyük çoğunluğunu 31-45 yaş aralığındaki orta yaş grubunun oluşturduğu görülmüsştür $(\mathrm{N}=142$, \%35.6). Buna karşın Erzurum ilinden katılanların büyük çoğunluğunu ise 18-25 aralığında bulunan gençler oluşturmuştur $(\mathrm{N}=179, \% 35,2)$. Erzurum ilinden araştırmaya katılan kişilerin büyük çoğunluğunun genç olmasının temel nedeni olarak il merkezinde, araştırmanın uygulandığı mekânlarda gençlerin oranının çok fazla olması gösterilebilir. Gümüşhane il merkezinde ise araştırmaya katılanların büyük çoğunluğunun orta yaş grubuna mensup kişilerden oluşmasının temel nedeni olarak da il merkezindeki çay ocaklarının büyük oranda orta yaş grubundaki kişiler tarafından tercih edildiği gösterilebilir. Aslına bakılırsa her iki bulgu da şunu göstermektedir ki; sosyal mekânlarda çay içmek çok tercih edilmekte ve çay, iletişim kurulması için gerekli ortama zemin hazırlayan bir içecek olarak görülmektedir.

Tablo 2'den elde edilen bir bulgu da her iki örneklem grubunda da araştırmaya katılanların büyük çoğunluğunu 1755-3500 arası gelir sahip orta gelir grubuna (Gümüşhane için N=182 (\% 45,6), Erzurum için N=124 (\%24,4)) sahip olan kişilerin oluşturmasıdır. Buna göre sohbetlerin vazgeçilmezi olan çayı en fazla tüketen grubun orta gelir grubuna sahip kişiler olduğu görülmektedir. Bu bakımdan çayın ekonomik bir içecek olduğu da söylenebilir.

Adı geçen tablodan ulaşılan bir diğer bulgu da çayın Gümüşhane il merkezinde daha ziyade evli insanlar tarafından tüketilirken ( $N=229, \% 57,4)$, Erzurum il merkezinde ise bekâr kişiler tarafından ( $\mathrm{N}=243, \% 47,7)$ tüketilmesi yönündedir. Bunun temel nedeni olarak yine Erzurum il merkezinde araştırmanın uygulandığı mekânlarda gençlerin 


\section{Gülsüm ÇALIŞIR, İhsan TÜRKAL, Burak TÜRTEN, Elif KÜTÜKOĞLU, Caner ÖZARSLAN, "Çay İçme Külttürünün Kișilerarası İletişime Katkısı" \\ Mavi Atlas, 7(2)/2019: 54-87}

ağırlıkta olması ve buna karşın Gümüşhane il merkezinde araştırmanın uygulandığ mekânlarda ise orta yaş grubunun fazla olması gösterilebilir.

Araştırmaya katılan kişilerin cinsiyetleri incelendiğinde de Gümüşhane ilindeki deneklerin büyük çoğunluğunu kadınların ( $\mathrm{N}=216, \%$ 54,1), Erzurum ilindeki deneklerin büyük çoğunluğunu ise erkeklerin oluşturduğu $(\mathrm{N}=226, \%$ 44,4) görülmektedir.

Tablo 2'ye bakıldığında araştırmaya katılanların eğitim durumları incelendiğinde ise her iki örneklem grubu içinde deneklerin büyük çoğunluğunu lisans mezunlarının (Gümüşhane için N=110 (\% 27,6), Erzurum için N=164 (\%32,2)) oluşturduğu izlenmektedir.

Tablo 2'den elde edilen bilgilere göre katılımcıların çayı en fazla tükettiği mekânın her iki örneklem grubu için de ev ortamı olduğu anlaşılmaktadır (Gümüşhane için $\mathrm{N}=146$ (\% 36,6), Erzurum için N=137 (\% 26,9)). Ev ortamında kişilerin zamanları daha fazla olduğu için çayın en fazla tüketildiği mekân olarak ev ortamı sonucunun çıkması, beklenen bir bulgudur. Buna karşın ev ortamından sonra kişilerin en fazla çay tükettikleri mekânın Gümüşhane için iş yerleri ( $\mathrm{N}=95, \%$ 23,8), Erzurum için ise kahvehaneler olduğu $(\mathrm{N}=69, \%$ 13,6) görülmektedir. Bu bulguyu, Gümüşhane ilindeki katılımcı kişilerin büyük çoğunluğunu orta yaş gelir grubuna sahip insanların oluşturması ve bu insanların büyük bölümünün iş sahibi olması nedeniyle çayı evlerinden sonra en çok vakit geçirdikleri iş yerlerinde tükettiklerini şeklinde yorumlamak mümkündür. Bunun yanı sıra Erzurum ilinden katılan kişilerin büyük çoğunluğunu 18-25 yaş arası genç grubu oluşturduğu ve bunların arasında iş sahibi olanların daha az olduğu varsayılırsa, bu insanların evlerinden sonra en çok zaman geçirdikleri mekânlar olan kahvehanelerde çay tüketme oranlarının daha yüksek olduğu ileri sürülebilir. Aynı zamanda Erzurum il merkezindeki insanlar arasında kahvehane kültürünün çok yaygın olması, bu mekânlarda çayın çok tüketilmesinin sebebi olarak da gösterilebilir.

Tablo 2'de verilen bir diğer bilgi de çayın tüketim saatine yöneliktir. Buna göre her iki örneklem grubunda da çayın en fazla tüketildiği saat 17:01-21:00 aralığında kalan zaman dilimidir (Gümüşhane ili için N=128 (\% 32,1), Erzurum ili için N=134 (\% 26,3)). Başka bir ifadeyle araştırmaya katılan kişiler, çayı daha çok akşam saatlerinde tüketmektedirler. Bu bağlamda bir yorum yapmak gerekirse, katılımcıların çayı daha çok akşamları ev ortamlarında günün yorgunluğunu atarken aile bireyleri ile sohbet aracı olarak tükettikleri söylenilebilir. Katılımcılar çayı daha çok aile bireyleri birlikte tüketmeyi tercih etmektedirler. Analiz bulgularına göre kişiler çayı en fazla ev ortamında ve aksam vakti (17:01-21:00) aile bireyleri ile birlikte tüketmeyi tercih etmektedirler. Bir 


\section{Gülsüm ÇALIŞIR, İhsan TÜRKAL, Burak TÜRTEN, Elif KÜTÜKOĞLU, Caner ÖZARSLAN, "Çay İçme Külttürünün Kișilerarası İletişime Katkısı" \\ Mavi Atlas, 7(2)/2019: 54-87}

başka deyişle kişiler çayı, daha çok aile bireyleri ile gerçekleştirdikleri iletişimlerinde bir araç olarak kullanmaktadırlar. Buna göre "Çay içmek, kişilerin aile bağlarını güçlendirmede olumlu bir rol oynamakta ve sohbetlerin ortağı olmaktadır.” şeklinde bir yoruma gitmek pek de yanıltıcı olmayacaktır. Bu yönüyle değerlendirildiğinde de aslında araştırmanın çıkış amacını doğrulayan bir bulguya ulaşıldığını ifade etmek mümkündür.

Araştırma kapsamında kullanılan 20 maddelik ankette ölçek yoluyla katılımcılardan elde edilen verilerin hangi faktörler altında toplandığını tespit edebilmek amacıyla "Keşfedici Faktör Analizi” uygulanmıştır. Bu doğrultuda Gümüşhane ölçeği için varimax dönüştürmesi kullanılarak, öz değeri 1'in üstünde olan 3 faktör ortaya konmuştur. Ölçekte bulunan 5 soru, birden fazla faktöre yüklendiği için ölçekten çıkarılmıştır. Bu üç faktör, toplam varyansın \% 69'unu açıklamaktadır. Söz konusu faktörler incelendiğinde birinci faktöre, içerdiği 4 sorunun niteliğinden dolayı "kişisel boyut" adı verilmiştir. 3 ve 8 sorudan oluşan İkinci ve üçüncü faktörlere ise sırasıyla; "birliktelik boyutu" ve "iletişim boyutu" isimleri verilmiştir. Örneklemin yeterliliğini ve kullanılan değişkenlerin faktör analizine uygunluğunu gösteren "Kaiser-Meyer-Olkin (KMO)" ile "Barlett Testi" kabul edilebilir sınırlar içerisinde bulunmuştur. Aynı zamanda kullanılan ölçeğin güvenirliğini gösteren Croanbach's Alpha değerleri "kişisel boyut" için, .891, "birliktelik boyutu" için .813 ve "iletişim boyutu” için .917 bulunmuştur. Gümüşhane ili için Keşfedici Faktör Analizine ilişkin bilgiler Tablo 3'te sunulduğu gibidir.

Tablo 3. Gümüşhane için keşfedici faktör analizi bulguları

Maddeler

Faktör Yükü

\begin{tabular}{|c|c|c|c|c|}
\hline \multirow{5}{*}{ 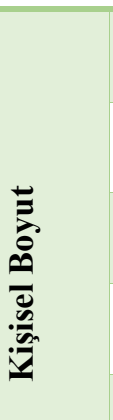 } & & F1 & $\mathbf{F} 2$ & F3 \\
\hline & Çay içmek beni rahatlatır. & .787 & & \\
\hline & Çay içmek insanı rahatlatır. & .792 & & \\
\hline & Stresli ve gergin olduğumda çay içmek iyi gelir & .837 & & \\
\hline & Sorunları çözerken çay içmek, insanı sakinleştirir. & .739 & & \\
\hline 言芦 & Başkaları ile birlikte çay içmek, insanı mutlu eder. & & 669 & \\
\hline
\end{tabular}


Gülsüm ÇALIŞIR, İhsan TÜRKAL, Burak TÜRTEN, Elif KÜTÜKOĞLU, Caner ÖZARSLAN, "Çay İçme Külttürünün Kişilerarası İletișime Katkısı"

Mavi Atlas, 7(2)/2019: 54-87

Arkadaşlarımla çay içmek keyiflidir.

Aile bireyleri ile çay içmek keyiflidir.

Çay içmek, sohbetlerin derinlik kazanmasına yol açar.

Çay içmek, kişiler arası iletişim aracı olarak kullanılabilir.

Çay içmek, sırların paylaşılmasına yardımcı olur.

Çay içmek, dertlerin paylaşılmasına yardımcı olur.

Çay içmek, dostluk ilişkilerini güçlendirir.

Çay içmek, insan ilişkilerine olumlu katkı sağlar.

Çay içmenin insanları bir araya getirme/toplama özelliği vardır.

Çay içmek, başkaları ile olan ilişkileri pekiştirir.

Barlett's test of Sphericity: 3994,367 (p<.000)

KMO Değeri: .925

Varyansın Açıklanma Oranı (\%)

Croanbach's Alpha
10.279

.891

7.022

Erzurum ölçeği için varimax dönüştürmesi kullanılarak, öz değeri 1'in üstünde 2 faktör ortaya konmuştur. Ölçekte bulunan 4 soru birden fazla faktöre yüklendiği için ölçekten çıkarılmıştır. Bu iki faktör toplam varyansın \% 66'sını açıklamaktadır. Söz konusu faktörler incelendiğinde birinci faktöre içerdiği 7 sorunun niteliğinden dolayı "kişisel ve birliktelik boyutu" adı verilmiştir. 9 sorudan oluşan ikinci faktöre ise "iletişim boyutu" adı verilmiştir. Örneklemin yeterliliğini ve kullanılan değişkenlerin faktör analizine uygunluğunu gösteren "Kaiser-Meyer-Olkin (KMO)" ile "Barlett Testi" kabul edilebilir sınırlar içerisinde bulunmuştur. Aynı zamanda kullanılan ölçeğin güvenirliğini gösteren Croanbach's Alpha değerleri birinci faktör için, .910, ikinci boyut için .936 
Gülsüm ÇALIŞIR, İhsan TÜRKAL, Burak TÜRTEN, Elif KÜTÜKOĞLU, Caner ÖZARSLAN, "Çay İçme Külttürünün Kişilerarası İletișime Katkısı"

Mavi Atlas, 7(2)/2019: 54-87

bulunmuştur. Erzurum ili için Keşfedici Faktör Analizi ile bilgilerin detaylı dökümü Tablo 4'te gösterildiği şekliyle aşağıda verilmiştir.

Tablo 4. Erzurum için keşfedici faktör analizi bulguları

Maddeler

Faktör Yükü

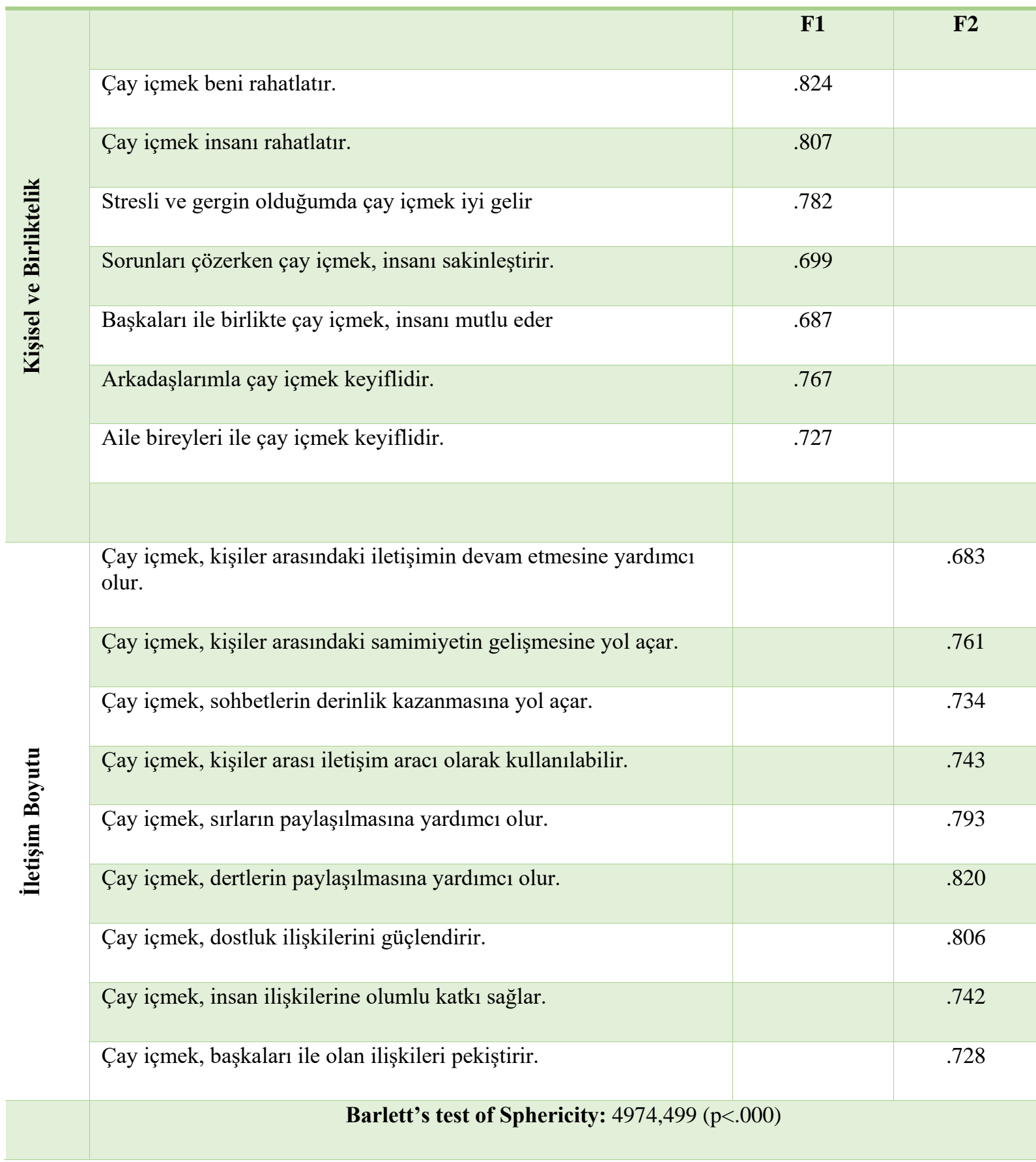


Gülsüm ÇALIŞIR, İhsan TÜRKAL, Burak TÜRTEN, Elif KÜTÜKOĞLU, Caner ÖZARSLAN, "Çay İçme Kültürünün Kişilerarası İletişime Katkısı"

Mavi Atlas, 7(2)/2019: 54-87

KMO Değeri: .930

Varyansın Açıklanma Oranı (\%)

11.399

55.104

Croanbach's Alpha

.910

.936

Araştırma kapsamında katılımcıların çay içme kültürlerinin cinsiyet ve medeni durum değişkenlerine göre anlamlı bir farklılık gösterip göstermediği Bağımsız Tek Örneklem T Testi ile test edilmiştir. Gümüşhane ili için katılımcıların cinsiyetlerine göre çay içme kültürleri arasında anlamlı bir farklılaşma bulunmamıştır. Buna göre Gümüşhane il merkezindeki insanlar için çay içmek her iki cins açısından da ortak bir değer ifade etmektedir. Başka bir ifadeyle Gümüşhane'de cinsiyet farklılığının, çay içme kültürü üzerinde hiçbir etkisi olmadığı sonucu ortaya çıkmıştır. Buna karşın katılımcıların medeni durumlarına göre çay içme kültürleri arasında anlamlı bir farklılaşma bulunmuştur. Söz konusu bulgular Tablo 5'te verilmiştir. İlgili tablo incelendiğinde, katılımcıların çay içme kültürleri ile medeni durumları arasında "kişisel boyut" ve "iletişim boyutu" açısından anlamlı bir farklılaşma olduğu görülmektedir. Buna göre Gümüşhane ilinde kişilerin medeni durumları, çay içme kültürleri üzerinde etkili olan bir faktör olarak dikkat çekmektedir.

Tablo 5. Gümüşhane için katılımcıların medeni durumuna ilişkin bağımsız tek örneklem $T$ testi B

N Ort. $\quad$ S.S. $\quad$ F-İstatistik t-İstatistik SD. Prob.

\begin{tabular}{|l|l|l|l|l|l|l|l|l|}
\hline Kişisel Boyut & Evli & 229 & 3.8865 & .93582 & 8.921 & 2.235 & 336.104 & $.026^{* *}$ \\
\hline & Bekâr & 170 & 3.6574 & 1.06616 & & & & \\
\hline Birliktelik B. & Evli & 229 & 4.2504 & .79374 & .827 & 1.626 & 397 & .105 \\
\hline & Bekâr & 170 & 4.1137 & .87639 & & & & \\
\hline İletişim B. & Evli & 229 & 3.8401 & .81977 & 6.462 & 2.328 & 328.527 & $.021 * *$ \\
\hline & Bekâr & 170 & 3.6265 & .96557 & & & & \\
\hline ** p<=0.05 & & & & & & & \\
\hline
\end{tabular}




\section{Gülsüm ÇALIŞIR, İhsan TÜRKAL, Burak TÜRTEN, Elif KÜTÜKOĞLU, Caner ÖZARSLAN, "Çay İçme Külttürünün Kişilerarası İletişime Katkısı" \\ Mavi Atlas, 7(2)/2019: 54-87}

Erzurum ilinden katılımcıların cinsiyet ve medeni durumlarına göre çay içme kültürleri arasında ise anlamlı herhangi bir farklılaşma bulunmamıştır. Buna göre Gümüşhane ili için H1 reddedilip H2 hipotezi kabul edilirken, Erzurum ili için her iki hipotez de reddedilmiştir.

Araştırma kapsamında katılımcıların gelir, yaş, eğitim durumu ve çayı en çok içtikleri mekân ve saat dilimleri değişkenlerine göre çay içme kültürleri arasında anlamlı bir farklılaşma olup olmadığı Tek Yönlü Anova Testi ile saptanmaya çalışılmıştır. Erzurum için bütün değişkenler ile çay içme kültürü arasında herhangi bir anlamlı ilişkiye rastlanılmamıştır. Erzurum il merkezi için bağımsız tek örneklem T testi ve tek yönlü Anavo test bulguları bir arada değerlendirildiğinde, bu şehirdeki insanlar için çay içmenin eğitim seviyesi ve yaş grubu ne olursa olsun, ister evli ister bekâr olsun ya da ister kadın ister erkek olsun toplumun tüm gelir gruplarına sahip olan insanlar tarafindan ortak bir değere sahip olduğu tespit edilmiştir. Literatür özeti bölümünde de verilen bilgiler bize çayın en fazla Erzurum'da tüketildiğini söylemektedir. Bu bilgiden de yola çıkarak Erzurum ilinde çayın toplumun her kesimine hitap eden bir içecek olduğunu söylemek mümkündür. Aynı zamanda araştırma bulgularından hareketle çayın Erzurum ilinde toplumun tamamını kuşatan, kişiler arasındaki iletişimi başlatan ve bu iletişimin devamını sağlayan bir içecek olduğunu ifade etmek mümkündür. Bu bulgu ayrıca, Erzurum ili ile ilişkili olarak yapılan çay araştırmalarında literatürdeki bulguları desteklemesi bakımında da değerli ve önemli olarak görülmektedir. Sonuç olarak Erzurum ili için H3, H4, H5, H6 ve $\mathrm{H7}$ hipotezleri reddedilmiştir.

Gümüşhane ili örneklemi için çay içme saati değişkenine göre çay içme kültürlerinin "kişisel boyut" açısından anlamlı farklılaştığı tespit edilmiştir. Söz konusu bulgular Tablo 6'da verilmiştir. Bulgular incelendiğinde söz konusu boyuta göre kişilerin öğleden önce ve öğleden sonra çay içme edimleri farklıdır. Bunun temel sebebi olarak sabah saatlerinde içilen çayın kahvaltı amaçlı olduğu, öğleden sonra içilen çayın ise daha çok sohbetlere ortak edilme amaçlı olduğu gösterilebilir. Sonuç olarak Gümüşhane ili örneklemi için H7 hipotezi kısmen doğrulanmıştır.

Tablo 6. Gümüşhane ili için çay içme saatine ilişkin tek yönlü anova test B

\begin{tabular}{|c|c|c|c|c|c|c|}
\hline & Kişisel Boyut & KT. & SD. & KO. & $\mathbf{F}$ & Prob. \\
\hline 05:00-09:00 & Gruplar Arasında & 12.385 & 5 & 2.477 & 2.532 & $.028 * *$ \\
\hline 09:01-13:00 & Grup İçinde & 384.513 & 393 & .978 & & \\
\hline
\end{tabular}


Gülsüm ÇALIŞIR, İhsan TÜRKAL, Burak TÜRTEN, Elif KÜTÜKOĞLU, Caner ÖZARSLAN, "Çay İçme Külttürünün Kişilerarası İletișime Katkısı"

Mavi Atlas, 7(2)/2019: 54-87

\begin{tabular}{|c|c|c|c|c|c|c|}
\hline 13:01-17:00 & $\begin{array}{l}\text { Birliktelik } \\
\text { Boyutu }\end{array}$ & & & & & \\
\hline 17:01-21:00 & Gruplar Arasinda & 2.015 & 5 & .403 & .580 & .716 \\
\hline 21:01-01:00 & Grup İçinde & 273.254 & 393 & .695 & & \\
\hline \multirow[t]{4}{*}{ 01:01-04:59 } & İletişim Boyutu & & & & & \\
\hline & Gruplar Arasında & 1.940 & 5 & .388 & .487 & .786 \\
\hline & Grup İçinde & 313.294 & 393 & .797 & & \\
\hline & \multicolumn{5}{|c|}{ Post Hoc Test Bulguları } & \\
\hline Bağımlı Değişken & Test Adı & (i) & (j) & $\mathbf{O F}(\mathbf{i - j})$ & S. Hata & Prob. \\
\hline \multirow[t]{2}{*}{ Kişisel Boyut } & Tukey HSD & 09:01-13:00 & 13:01-17:00 & -.45300 & .13346 & $.010^{* * *}$ \\
\hline & Scheffe & 09:01-13:00 & 13:01-17:00 & -.45300 & .13346 & $.044 * *$ \\
\hline & & & & & & \\
\hline & & & & & & \\
\hline
\end{tabular}

Gümüşhane ili için katılımcıların yaşlarına göre çay içme kültürleri arasında tüm faktör boyutları açısından anlamlı bir farklılaşma olduğu tespit edilmiştir. Test bulguları Tablo 7'de verilmiştir. Bulgular incelendiğinde 18-25 arası yaş grubu gençlerin çay içme kültürleri, 26-30 ve 31-45 arası yaş grubu kişilerin çay içme kültürlerine göre farklılaşmaktadır. Aynı zamanda 26-30 arası yaş grubun çay içme kültürleri, 31-45 arası yaş grubuna göre anlamlı farklılaşma göstermektedir. Gümüşhane ili örneklemi için H5 hipotezi doğrulanmıştır.

Tablo 7. Gümüşhane ili için yaş değişkenine ilişkin tek yönlü anova test $B$

\begin{tabular}{|c|c|c|c|c|c|c|}
\hline & Kişisel Boyut & KT. & SD. & KO. & F & Prob. \\
\hline $\mathbf{1 8 - 2 5}$ arası & Gruplar Arasında & 15.799 & 4 & 3.950 & 4.073 & $.003 * *$ \\
\hline $\mathbf{2 6 - 3 0}$ arası & Grup İçinde & 381.098 & 393 & .970 & & \\
\hline
\end{tabular}


Gülsüm ÇALIŞIR, İhsan TÜRKAL, Burak TÜRTEN, Elif KÜTÜKOĞLU, Caner ÖZARSLAN, "Çay İçme Külttürünün Kişilerarası İletișime Katkısı"

Mavi Atlas, 7(2)/2019: 54-87

\begin{tabular}{|c|c|c|c|c|c|c|}
\hline $31-45$ arası & $\begin{array}{c}\text { Birliktelik } \\
\text { Boyutu }\end{array}$ & & & & & \\
\hline 46-55 arası & Gruplar Arasında & 6.695 & 4 & 1.674 & 2.451 & $.046^{* *}$ \\
\hline \multirow[t]{5}{*}{56 ve üstü } & Grup İçinde & 268.348 & 393 & .683 & & \\
\hline & İletişim Boyutu & & & & & \\
\hline & Gruplar Arasında & 8.385 & 4 & 2.096 & 2.699 & $.030 * *$ \\
\hline & Grup İçinde & 305.280 & 393 & .777 & & \\
\hline & \multicolumn{5}{|c|}{ Post Hoc Test Bulguları } & \\
\hline Bağımlı Değişken & Test Adı & (i) & (j) & $O F(i-j)$ & S. Hata & Prob. \\
\hline \multirow[t]{2}{*}{ Kişisel Boyut } & Games-Howell & $18-25$ aras1 & $26-30$ aras 1 & -.45070 & .15510 & $.033 * *$ \\
\hline & & & $31-45$ aras1 & -.47783 & .13702 & $.005^{* * *}$ \\
\hline Birliktelik Boyutu & Tukey HSD & $26-30$ aras1 & $31-45$ aras1 & -.31248 & .12186 & $.079^{*}$ \\
\hline \multirow[t]{2}{*}{ İletişim Boyutu } & Tukey HSD & $18-25$ aras 1 & $31-45$ aras1 & -.36916 & .11344 & $.011 * *$ \\
\hline & Scheffe & $18-25$ aras1 & $31-45$ aras 1 & -.36916 & .1134 & $.033 * *$ \\
\hline & & & & & & \\
\hline
\end{tabular}

Gümüşhane ili için katılımcıların eğitim durumlarına göre çay içme kültürleri arasında "birliktelik Boyutu" açısından \% 10 anlamlılık düzeyinde bir farklılaşma bulunmuştur. Test bulguları Tablo 8'de verilmiştir. Bulgular incelendiğinde ön lisans grubuna mensup kişilerin çay içme kültürleri, lisansüstü grubuna mensup kişilerin çay içme kültürlerine kıyasla farklılaşmaktadır. Gümüşhane ili örneklemi için H3 hipotezi doğrulanmıştır.

Tablo 8. Gümüşhane ili için eğitim değişkenine ilişkin tek yönlü anova test B
Kişisel Boyut
KT.
SD.
KO.
F
Prob. 
Gülsüm ÇALIŞIR, İhsan TÜRKAL, Burak TÜRTEN, Elif KÜTÜKOĞLU, Caner ÖZARSLAN, "Çay İçme Külttürünün Kişilerarası İletișime Katkısı"

Mavi Atlas, 7(2)/2019: 54-87

\begin{tabular}{|c|c|c|c|c|c|c|}
\hline İlköğretim & Gruplar Arasında & 3.113 & 4 & .778 & .779 & .540 \\
\hline Lise & Grup İçinde & 393.785 & 394 & .999 & & \\
\hline Ön lisans & $\begin{array}{l}\text { Birliktelik } \\
\text { Boyutu }\end{array}$ & & & & & \\
\hline Lisans & Gruplar Arasında & 5.621 & 4 & 1.405 & 2.053 & $.086^{*}$ \\
\hline \multirow[t]{5}{*}{ Lisans Üstü } & Grup İçinde & 269.647 & 394 & .684 & & \\
\hline & İletişim Boyutu & & & & & \\
\hline & Gruplar Arasında & 6.214 & 4 & 1.554 & 1.981 & $.097^{\mathrm{a}}$ \\
\hline & Grup İçinde & 309.020 & 394 & .784 & & \\
\hline & \multicolumn{5}{|c|}{ Post Hoc Test Bulguları } & \\
\hline $\begin{array}{l}\text { Bağımlı } \\
\text { Değiş̧ken }\end{array}$ & Test Adı & (i) & (j) & $\mathrm{OF}(\mathrm{i}-\mathrm{j})$ & S. Hata & Prob. \\
\hline $\begin{array}{l}\text { Birliktelik } \\
\text { Boyutu }\end{array}$ & Games Howell & Ön lisans & Lisans Üstü & -.39625 & .14398 & $.052^{* *}$ \\
\hline
\end{tabular}

a; İletişim boyutuna ilişkin Prob değeri 0.97 olmasına karşın \%10 anlamlılık düzeyinde bir farklılaşma gözlenmemiştir.

Gümüşhane ili örneklemi için çay içilen mekân ve gelir değişkenlerine göre katılımcıların çay içme kültürleri arasında anlamlı farklılaşma bulunmamıştır. Başka bir ifadeyle Gümüşhane ili için H4 ve H6 hipotezleri reddedilmiştir.

\section{Sonuç}

Binlerce yıl önce Uzak Doğu'da başlayan serüveni ile dikkati çeken ve yolculuğunun önemli duraklarından biri olan Anadolu topraklarına geldiğinde ise büyük beğeni toplayan ve neredeyse en çok tüketilen içecek olan çay, dünden bugüne gelinen süreçte vazgeçilmez içeceklerden birisi olmuştur. Soğuk kış günlerinde içimizi ssıtırken, kavurucu sıcaklarda da hararetimizi alması için tükettiğimiz çay, öylesine geçiştirilecek bir içecek olmadığını zaman içerisinde bize göstermiştir. Literatürde verilen bilgiler göstermiştir ki, çayın uzun yıllar önce başlayan yolculuğu pek çok durakta kendine yer bulmuştur. Söz konusu duraklar içerisinde de en çok kaldığı ve benimsendiği topraklar 


\section{Gülsüm ÇALIŞIR, İhsan TÜRKAL, Burak TÜRTEN, Elif KÜTÜKOĞLU, Caner ÖZARSLAN, "Çay İçme Kültürünün Kişilerarası İletişime Katkısı" \\ Mavi Atlas, 7(2)/2019: 54-87}

Anadolu olmuştur. Anadolu kültürüne kahveden sonra girse de girdiği andan itibaren halkın çoğunluğunu kendine bağlayan bir içecek olmuştur çay.

Türkiye'de çayın yetiştirilmesi 1940'lı yıllara dayanmaktadır. Geçtiğimiz yıllar boyunca bu lezzet kendine önemli yer edinmiş ve sosyal yaşamın vazgeçilmez bir parçası haline gelmiştir. Kısacası çay ve ona ait olan kültür, bizden birisi olmuştur ve bizi kısa sürede sarıp sarmalayan bir içecek olmuştur. Anadolu' da hemen her çatının altında günde en az bir kez çay demlendiği ve tüketildiğini söylemek pek de abartı olmasa gerek. Çay artık bizim kültürümüzün bir parçası olurken, kendine ait de bir kültür oluşturarak Türk kültürünün en başat aktörlerinden birisi haline dönüşmüştür.

Türk kültüründe var olan bir söz şöyle der: "Çaysız sohbet, aysız gökyüzü gibidir." Bir diğer söz de "Neyse ki çayın demi var, yaşamın gamına inat." Haşmet Babaoğlu ise "Çayın kalabalıkla arası iyidir, kahve yalnızlık ister" diyerek, aslında bu çalışmanın amacını doğrulamaktadır. Burada verilen bu sözler de göstermektedir ki çay, toplumun geneline hitap eden bir içecek olmanın yanı sıra, toplumu kucaklamakla kalmayıp, toplumun bireylerini birbirine yaklaştıran, kaynaştıran, bu yönüyle de iletişimin devamına olanak tanıyan bir özelliğe sahip olmaktadır.

Çay söz konusu olduğunda literatürde yetiştirilmesinden, tüketimine, sektördeki durumundan, kültür içinde nasıl yer aldığına dair pek çok sayıda çalışma yapıldığ görülmektedir. Ancak çay ve iletişim bağlamında bir çalışmanın yapılmamış olması, araştırmacıların dikkatini bu yöne çekmiştir. Bir de araştırmacıların çayın en çok üretildiği ve tüketildiği bölgelere yakın bir yerde yaşıyor olması, böylesi bir çalışma yapma fikrini ortaya çıkartmıştır. Bu düşüncelerden hareketle çayın kişilerarası iletişime ne yönde katkı sağladığı merak edilmiş ve bu merakın giderilebilmesi için bu çalışma gerçekleştirilmiştir.

Bu çalışmada, öncelikle çay içme kültürünün kişilerarası iletişime katkısının olup olmadığı yönünde bilgilere ulaşılmak istenmiştir. Araştırmacıların Gümüşhane'de yaşıyor olması ve çayın en çok tüketildiği Erzurum iline yakın olması nedeniyle çalışmada örneklem olarak, adı geçen iki il seçilmiştir. Söz konusu illerde kişilerin çay içme kültürüne dair sahip olduğu değerler ile çay ve iletişim arasında nassll bir ilişki kuruduklarını anlamaya yönelik olarak bir ölçek geliştirilmiştir. Akabinde de her iki ilde toplamda 800 katılımcı ile yüz yüze görüşmeler yapılmış ve kendilerine anket uygulanmıştır.

Anket uygulaması sırasında katılımcılarla gerçekleştirilen görüşmelerde elde edilen sözel bilgilere göre her iki ilde de çay fazlasıyla tüketilmektedir. Anket soruları 


\section{Gülsüm ÇALIŞIR, İhsan TÜRKAL, Burak TÜRTEN, Elif KÜTÜKOĞLU, Caner ÖZARSLAN, "Çay İçme Külttürünün Kişilerarası İletişime Katkısı" \\ Mavi Atlas, 7(2)/2019: 54-87}

içerisinde çayın en çok hangi ilde tüketildiğini belirlemeye yönelik bir soru olmamasına rağmen, katılımcıların söylemlerinden edilen bilgi, bu sonucu da görünür kılmaktadır. Yazılı olarak görülmese de sözel olarak bizzat anketi uygulayan araştırmacıların kayıt altına aldığı bu bilgiye göre çay çok tüketilmekte ve çok sevilen içecekler listesinde ilk sıralarda yer almaktadır. Hatta öyle ki çay, toplumun hemen her kesimi (genç-yaşlı, gelir seviyesi düşük-yüksek, kadın-erkek, eğitim seviyesi düşük-yüksek, çalışan-çalışmayan vb.) tarafından içimi tercih edilen bir içecek durumundadır. Türkiye'de çay tüketimi davranış1 incelendiğinde, söz konusu davranışın bölgelere göre farklılık gösterdiği görülmektedir. Örneğin Güneş’in (2012) belirttiği gibi Erzurum'da kişiler açık demli çayı tüketmeyi tercih ederlerken, Gümüşhane ilinde kişiler orta demli çay içmeyi tercih etmektedir.

$\mathrm{Bu}$ araştırmada anket sorularına verilen cevaplardan elde edilen bilgiler bize sadece katılımcıların demografik bilgilerini vermekle kalmıyor. Çalışmada çayın kimler tarafından tüketildiğini gösteren bilgilerin dışında, sorulan daha detaylı sorularla katılımcılardan çay ve kişilerarası iletişim başlıkları ile ilgili neler düşündüklerini ortaya koyan bilgiler de alınmaya çalışılmıştır. Buna göre katılımcıların çay içme edimlerini genellikle yanlarında aile bireyleri, arkadaşları vb. kişiler olduğunda gerçekleştirmekten hoşnut oldukları yönünde bilgilere ulaşılmıştır. Bu durum bizi çalışmanın çıkış noktasını doğrulayan bilgilere götürmektedir. Zira katılımcılar verdikleri cevaplar ile çay içme kültürünün kişilerarası iletişime zemin hazırlayan ve bu eylemin gerçekleşmesine olanak tanıyan bir durum olduğunu dile getirmişlerdir. Bu bilgiden hareketle çayın birlikte içilmekten keyif alınan ve kişileri bir araya toplama ve iletişimi sürekli hale dönüştürme özelliğine sahip bir içecek olduğundan söz etmek mümkündür.

Araştırmada ilk olarak katılımcıların anket sorularına verdikleri cevapların ortalaması incelenmiştir. Buna göre her iki ilde katılımcıların anket ölçeklerine verdikleri yanıtların ortalamasının çok yüksek olduğu görülmüştür. Dolaysıyla katılımcıların anket sorularını anlayarak cevapladıkları söylenebilir. Hem Gümüşhane ili için hem de Erzurum ili için ölçeğe verilen yanıtların ortalaması incelendiğinde kişilerin aile bireyleri, arkadaşları ve başkalarıyla çay içmeyi çok önemsedikleri ve dolaysıyla da çayı iletişim kurmada önemli bir araç olarak gördükleri sonucuna varılmıştır. Bu önemli bir bulgudur. Zira toplumların kültürel tarihleri incelendiğinde belirli değerler, adet, gelenek-görenek ve yerel lezzetler gibi unsurların toplumun kendisiyle özdeşleştiği ve her bir bireyin ortak paydası haline geldiği anlaşılmıştır. Bu bakımdan çay her ne kadar küresel bir lezzet olarak kabul edilse de Türk toplumu tarafından milli bir lezzet (içecek) olarak içselleştirilmiştir. Buna göre kişiler günlük yaşamlarında iletişim kurmada çayı önemli 


\section{Gülsüm ÇALIŞIR, İhsan TÜRKAL, Burak TÜRTEN, Elif KÜTÜKOĞLU, Caner ÖZARSLAN, "Çay İçme Külttürünün Kișilerarası İletişime Katkısı" \\ Mavi Atlas, 7(2)/2019: 54-87}

bir araç olarak görmenin yanında, bu içeceği vazgeçilmez bir lezzet olarak benimsemişlerdir.

Araştırmada elde edilen bulgular kişilerarası iletişim bağlamında değerlendirildiğinde, çay içme kültürü ve kişilerarası iletişim ile aralarında bir bağ kurulduğu belirlenmiştir. Zira çay tüketimi Türk toplumunda çift yönlü iletişime zemin hazırlamaktadır. Bu durum aynı zamanda kişilerarası iletişımin varlığına işaret etmektedir. Nitekim söz konusu iletişim türü, en az iki kişi arasında gerçekleşmektedir ve iletiler karşılıklı olarak iletilmektedir (Gürüz ve Temel Eğinli, 2012). Bu yönüyle bakıldığında çayın özellikle başkalarıyla birlikte tüketilmesi, kişilerarası iletişime olanak sağlamasının yanında sosyalleşmeyi de beraberinde getirmektedir. Ayrıca elde edilen bulgular, çay tüketim şeklinin bu iki il içinde farklı olmasına rağmen her iki ilde yaşayan kişiler için çayın birleştirici rolünü ön plana çıkarttığını göstermiştir. Araştırmadan elde edilen bu bulgu, Türk toplumunun birlikte yaşama ve paylaşma arzusunun gücünü ve de misafirperverliğe ne kadar önem verdiğini göstermesi bakımından da önemlidir. Çayın birliktelik özelinde Türk toplumunda önemli bir yere sahip olduğunu ortaya koyması literatürdeki Yağbasan ve Ustakara (2008), Güneş (2012) ile Ustakara ve Burhan (2017)'ın çalışmalarını desteklemektedir. Zira Güneş (2012) çayın Türk toplumu içerisinde ne denli önemli olduğunu tarihsel olarak ortaya koyarken, Ustakara ve Burhan (2017) ile Yağbasan ve Ustakara (2008) kahvehanelerin, ki Türk toplumunda bu mekanlarda neredeyse sadece çay tüketilmektedir, iletişim kurmada önemli bir araç olduğunu göstermişlerdir.

Araştırma kapsamında aynı zamanda her iki ilde çay içme kültürünün iletişime katkısının demografik faktörler tarafından belirlenip belirlenmediği saptanmaya çalışılmıştır. Buna göre Erzurum ilinde çay tüketimi cinsiyete ve medeni duruma göre farklılaşma göstermemektedir. Başka bir ifadeyle bu ilde yaşayan kişilerin çay içme kültürleri üzerinde cinsiyet ve medeni durumun bir etkisi söz konusu değildir. Gümüşhane ili içinse çay tüketimi cinsiyete göre farklılaşma göstermezken, medeni duruma göre anlamlı bir farklılaşma söz konusudur. Buna göre bu ilde çay içme kültürü üzerinde kişilerin medeni durumunun önemli bir etkisi vardır. Çay içme kültürü üzerinde Erzurum ili için gelir, yaş, eğitim durumu, mekân ve zaman faktörlerinin anlamlı herhangi bir etkisi tespit edilmemiştir. Bu bağlamda Erzurum'da çay tüketiminin toplumun bütün kesimleri tarafından benimsendiği ve ortak bir değer olarak görüldüğü söylenebilir. Başka bir ifadeyle çay içme kültürünün bu ildeki kişiler tarafından cinsiyet, eğitim düzeyi, gelir durumu ve zaman ile mekân algısı gibi unsurlardan etkilenmeyecek kadar içselleştirdiği bir lezzet olduğunu göstermektedir. 


\section{Gülsüm ÇALIŞIR, İhsan TÜRKAL, Burak TÜRTEN, Elif KÜTÜKOĞLU, Caner ÖZARSLAN, "Çay İçme Külttürünün Kișilerarası İletişime Katkısı" \\ Mavi Atlas, 7(2)/2019: 54-87}

Gümüşhane ilinde ise çay içme kültürü kişilerin yaşları, eğitim düzeyleri ve tüketim zamanına göre anlamlı bir şekilde farklılaşmaktadır. Buna göre bu ilde yaşayan kişilerin çay tüketimi davranışları üzerinde söz konusu faktörlerin önemli bir etkisi bulunmaktadır. Gümüşhane ili özelinde elde edilen bulgulardan en dikkat çekenlerini şu şekilde özetlemek mümkündür: İlk bulgu, çay içme saati değişkenine göre çay içme kültürü ile ilişkili olarak katılımcıların öğleden önce ve öğleden sonra çay içme edimlerinin birbirinden farklı olduğu yönündedir. Elde edilen bilgiler, çayın öğleden sonra daha fazla tüketildiğini göstermektedir. Bunun temel gerekçesini, sabah tüketilen çayın kahvaltı amaçlı olarak, öğleden sonra tüketilen çayın ise daha çok iletişim ortamlarını zenginleştirmesi amacıyla olabileceği şeklinde açıklamak mümkündür. Bu bulgu da çalışmanın başlığını doğrulayan ve çalışmanın gerçekleştirme amacı ile uygunluk göstermesi bakımından değerlidir. Zira katılımcılar, ankette soruları cevaplarken çayı hem öğleden sonra hem de tanıdıkları ile daha fazla tükettikleri yönünde bilgiler vermiştir. İkinci bulgu da Gümüşhane'de bulunan katılımcıların yaşlarına göre çay içme kültürleri arasında tüm faktör boyutları açısından anlamlı bir farklılaşma olduğu ile ilgilidir. Araştırma bulgularına göre Gümüşhane ilinde yaş gurubu ile çay içme edimleri arasındaki farka bakıldığında, orta yaş grubunda bulunan katılımcıların daha yoğunlukta olduğu görülmektedir. 31-45 yaş aralığında yer alan katılımcıların, diğer yaş aralığında bulunan katılımcılara göre fazla olmasını, Gümüşhane'de genç nüfus oranının Erzurum iline göre daha az olması şeklinde açıklamak yerinde olacaktır. Keza, Erzurum, hem büyük şehir olması hem de merkez il sınırları içerisinde iki üniversite bulundurması bakımıyla genç nüfusun daha yoğun olarak yaşadığı bir il konumundadır. Oysa Gümüşhane, hem Erzurum'a göre küçük bir ildir hem de il merkezinde üniversite öğrenci sayısı Erzurum kadar çok değildir. Nitekim Erzurum Atatürk Üniversitesi 1957 yılında (https://atauni.edu.tr/kurulus-oykusu, 2018) kurulan köklü bir üniversite iken; Gümüşhane Üniversitesi 2008 y1lında (http://www.gumushane.edu.tr/tarihce, 2018) kurulmuş, nispeten daha yeni bir üniversitedir. Üniversite öğrencilerinin yaş ortalamalarının da 18-25 aralığında olduğu göz önünde bulundurulduğunda, Gümüşhane'de bu yaş aralığında bulunan katılımcı sayısının göreli olarak daha az olduğunu söylemek yanlış bir bilgi olmayacaktır. Gümüşhane'de çay içme kültürü mekân ve gelir dağılımına göre anlamlı bir farklılaşma göstermemektedir.

Araştırma genel olarak değerlendirildiğinde, çay içme kültürünün kişilerarası iletişime katkısını somut bir şekilde ortaya koyması bakımından önemlidir ve aynı zamanda özgün bir yapıya sahiptir. Çalışmadan elde edilen bulgular, bundan sonra bu konuyla ilgili yapılacak konulara veri oluşturması bakımından değerlidir. Bunun yanında 


\section{Gülsüm ÇALIŞIR, İhsan TÜRKAL, Burak TÜRTEN, Elif KÜTÜKOĞLU, Caner ÖZARSLAN, "Çay İçme Külttürünün Kişilerarası İletişime Katkısı" \\ Mavi Atlas, 7(2)/2019: 54-87}

farklı iki toplum arasında çay tüketimi davranışı üzerinde cinsiyet, gelir dağılımı, yaş, eğitim düzeyi ve mekân ile zaman dilimi gibi faktörlerin anlamlı bir farklılaşmasının olup olmadığını göstermesi bakımından diğer çalışmalardan ayrışmaktadır. Ancak bundan sonra bu konunun farklı boyutları da ele alınıp incelenebilir. Örneğin bu çalışma sadece Gümüşhane ve Erzurum özelinde gerçekleştirilmiştir. Bundan sonra bu konuda yapılacak olan çalışmalar, araştırmacılar tarafından Türkiye'nin yedi bölgesini de kapsayacak şekilde irdelenebilir. Bunun yanı sıra bu çalışmada nicel araştırma yöntemi tercih edilmiştir. Daha sonra bu konuda araştırma yapmak isteyen araştırmacılar, konunun bu yönüne nitel araştırma yöntemlerinden olan derinlemesine görüşme ve yarı yapılandırılmış görüşme yöntemlerini de kullanarak, çalışmalarında daha derinlemesine bilgilere de ulaşabilirler. Konu ele alınıp incelenmesi geniş kapsamlı bir konu olması bakımından, bundan sonra da çay içme kültürünün farklı bilim alanları ile bağlantısı kurulabilir. Bu anlamda zengin bir literatür bilgisi ve geniş bir araştırma alanı olması bakımından çay içme kültürü, bundan sonra da pek çok çalışmaya konu ve malzeme olabilir. Özetle; bundan sonra bu konu ile ilgili gerçekleştirilecek araştırmaların gerek Türk toplumunda çay tüketiminin yerini daha net bir şekilde ortaya koyması ve gerekse de literatürün ilgili alanına katkı sağlaması düşünülmektedir.

\section{Kaynakça}

\section{Periyodik Yayın:}

GÜNEŞ, Serkan (2012). “Türk Çay Kültürü ve Ürünleri”, Milli Folklor Dergisi, Y11: 24, Say1: 93: 234-251.

USTAKARA, Fuat ve E. BURHAN (2017). "Toplumsal İletişim Kurumu Olarak Kahvehanelere Dair Bir Araştırma: Gaziantep Örneği”, Erciyes İletişim Dergisi academia 2017, Cilt: 5, Say1: 2: 210-226.

YAĞBASAN, M. ve Fuat USTAKARA (2008). "Türk Toplumunda Kahvehane ve Kafelerde İletişimsel Ortamı Belirlemeye Yönelik Bir Alan Araştırması (Gaziantep İli Örneği), Firat Üniversitesi Sosyal Bilimler Dergisi, Cilt: 18, Sayı: 1: 233-260.

\section{Kitaplar:}

BAYKARA, Tuncer (2001). Türk Kültür Tarihine Bakışlar, Ankara: Atatürk Kültür Merkezi Başkanlığg1 Yayınları.

DEVITO, Joseph A. (1995). The Interpersonal Communication Book, (Seventh Edition), New York: Harper Collins Collage Publishers. 
Gülsüm ÇALIŞIR, İhsan TÜRKAL, Burak TÜRTEN, Elif KÜTÜKOĞLU, Caner ÖZARSLAN, "Çay İçme Kültürrünün Kişilerarası İletişime Katkısı"

Mavi Atlas, 7(2)/2019: 54-87

DÖKMEN, Üstün (2001). İletişim Çatışmaları ve Empati, İstanbul: Sistem Yayınc1lik.

DUMAN, Mustafa (2008). Çay Kitabı, İstanbul: Kitabevi Yayınları.

GÜRSOY, Deniz (2005). Demlikten Süzülen Kültür: Çay, İstanbul: Oğlak Yayınevi.

GÜRÜZ, Demet ve Ayşe TEMEL EĞİNLİ (2012). Kişilerarası İletişim BilgilerEtkiler-Engeller, (3. Basım), Ankara: Nobel Akademik Yayıncılık.

HARTLEY, Peter (2010). Kişilerarası İletişim, (Çevirenler: Ülkü Doğanay, Melike Aktaş Yamanoğlu, Burcu Şimşek, Pınar Özdemir, Halise Karaaslan Şanlı, İnan Özdemir Taştan), (1. Bask1), Ankara: İmge Kitabevi.

KAÇAR, Burhan (2010). Çay Bitkisi, Biyokimyası, Gübrelenmesi, İşleme Teknolojisi, Ankara: Nobel Yayınları.

KÖPRÜLÜ, Mehmet Fuad (2003). Türk Edebiyatında İlk Mutasavvıflar, Ankara: Akçă̆ Yayınları.

KUZUCU, Kemalettin (2012). Bin Yılın Çayl, Osmanlı'da Çay ve Çayhane Kültürü, İstanbul: Kapı Yayınları.

OĞUZ, Burhan (1976). Türkiye Halkının Kültür Kökenleri, Cilt 1, İstanbul: İstanbul Matbaas1.

REIMERTZ, Stephan (2003). Çayın Kültür Tarihi, (Çeviren: Mustafa Tüzel), (2. Bask1), Ankara: Dost Kitabevi.

RUFFNER, Michael and BURGOON Michael (1981). Interpersonal Communication, Harcourt School Publication.

SİYEZ, Diğdem (2015). Kişilerarası İlişkilerin Başlangıcı ve Gelişimi, Kişilerarası İlişkiler ve Etkili İletişim, (7. Baskı), Editör: Kaya, A., Ankara: Pegem Akademi.

USLUATA, Ayseli (1994). İletişim, Cep Üniversitesi, (1. Bask1), İstanbul: İletişim Yayınları. 
Gülsüm ÇALIŞIR, İhsan TÜRKAL, Burak TÜRTEN, Elif KÜTÜKOĞLU, Caner ÖZARSLAN, "Çay İçme Külttürünün Kişilerarası İletișime Katkısı"

Mavi Atlas, 7(2)/2019: 54-87

\section{Tezler:}

ÇİMEN, Kemal (2014). Türkiye'de Çay Yetiştiriciliği ve Çay Sanayii, (Yayımlanmamış Yüksek Lisans Tezi), İstanbul Üniversitesi, Sosyal Bilimler Enstitüsü, İstanbul.

GENÇ, Fatma (2010). Türkiye'de Çay Üretimi ve Değişen Sosyal İlişkiler, (Yayımlanmamış Yüksek Lisans Tezi), Marmara Üniversitesi, Sosyal Bilimler Enstitüsü, İstanbul.

KORKMAZ, Furkan (2012). Türkiye Çay Sektörünün Mevcut Durumu ve Bir Çay Fabrikasında Enerji Verimliliği, (Yayımlanmamış Yüksek Lisans Tezi), İstanbul Teknik Üniversitesi, Enerji Enstitüsü, İstanbul.

TATOĞLU, Mehmet (2017). Küresel Marka Oluşturmada Yürütülen İletişim Stratejileri: Çaykur ve Lipton Örneği, (Yayımlanmamış Doktora Tezi), Maltepe Üniversitesi, Sosyal Bilimler Enstitüsü, İstanbul.

\section{Internette Yer Alan Metinler:}

“Atatürk Üniversitesi”, Erişim Tarihi: 25 Nisan 2018, (https://atauni.edu.tr/kurulus-oykusu).

"Bir Bardak Çayın Hikayesi”, Erişim Tarihi: 21 Ocak 2018, (http://medyamutfagi.blogcu.com/bir-bardak-cayin-hikayesi/12106400)

"Gümüşhane Üniversitesi”, Erişim Tarihi: 25 Nisan 2018, (http://www.gumushane.edu.tr/tarihce).

"Kültüre Göre Çay", Erişim Tarihi: 20 Ocak 2018, (http://www.kerimusta.com/kulturlere-gore-cay/?print=pdf).

TEZCAN, Mahmut (1987). "Erzurum Kültürü ve Kişiliği”, 11-14 Mart tarihleri arasında Erzurum'da gerçekleştirilen 'Tarihi Akış İçinde Erzurum' konulu sempozyumda sunulan tebliğ, $\quad$ Erişim $\quad$ Tarihi: $23 \quad$ Ocak 2018. (http://dergiler.ankara.edu.tr/dergiler/40/518/6487.pdf). 